\title{
THE SOCIAL ORIGINS AND SCHOOLING OF A SCIENTIFIC Elite: \\ FELLOWS OF THE ROYAL SOCIETY BORN FROM 1900
}

\section{Erzsébet Bukodi}

\author{
Department of Social Policy and Intervention, \\ Nuffield College \\ University of Oxford \\ Erzsebet.bukodi@nuffield.ox.ac.uk
}

John H. Goldthorpe

Nuffield College

University of Oxford

John.goldthorpe@nuffield.ox.ac.uk

Inga Steinberg

Department of Social Policy and Intervention,

Nuffield College

University of Oxford

Inga.steinberg@nuffield.ox.ac.uk 
ABSTRACT

We present an analysis of the social composition of the UK scientific elite, as represented by Fellows of the Royal Society, in terms of Fellows' social class origins and type of secondary education. From various sources, we have assembled data for 1691 Fellows, representing 80\% of our target population of all Fellows born from 1900 onwards whose scientific careers were spent predominantly in the UK. We find that while these elite scientists come largely from more advantaged class backgrounds, it is professional rather than business or managerial families that are the main source of their recruitment - and, increasingly, such families where a parent is in a STEM occupation. Recruitment from working-class families has declined and for most recent birth cohorts almost ceased. The scientific elite is thus now more homogenous as regards the social origins of its members than it was in the second half of the twentieth century. At the same time, little change is evident in the secondary schooling of Fellows. In all birth cohorts, between two-fifths and a half of all - and over two-thirds of those from more advantaged class backgrounds - were privately educated, although the proportion attending Clarendon schools would seem low compared with that in other elites. A further finding is that both class origins and type of schooling are associated the relative probabilities of Fellows working in different research fields.

\section{ACKNOWLEDGEMENTS}

We are duly grateful to the McGrath Trust that made our research possible. We are also grateful to David Cox, Jouni Kuha, Kenneth Macdonald and Lee Elliott Major for their very helpful comments on earlier versions of this paper. 
INTRODUCTION

This paper is the first in a planned series on the sociology of the UK scientific elite, as represented by Fellows of the Royal Society. In this research, we aim to exemplify a new approach to elite studies that we have outlined elsewhere (Bukodi and Goldthorpe, forthcoming) and that, we believe, treats questions of the social composition, openness, and power or, more generally, effectiveness of elites in a more integrated way than hitherto. We hope eventually to extend this approach to a range of elites. But our initial focus on a scientific elite reflects our view that in the context of rising concern over such issues as global warming, pandemics, and the threats as well as the potential of Al, greater research attention needs to centre on scientific elites in view of the increasingly important sociopolitical role that they would seem destined to play.

The study of scientific elites has in fact a long, though rather discontinuous, history, and has been driven by significantly differing interests.

In the nineteenth century, a central concern was with the relative importance of heredity and environment in the creation of scientific genius. A notable controversy on this issue occurred between Francis Galton and the Swiss botanist, Alphonse de Candolle. Relying mainly on the analysis of pedigrees, including those of Fellows of the Royal Society, Galton $(1869,1874$; Galton and Schuster, 1906) persisted in the view that heredity was the dominant factor in outstanding intellectual achievement in all fields, science included. Such achievement 'ran in families', and those few men from hitherto undistinguished families who rose to intellectual eminence - as, say, through being elected Fellows of the Royal Society - were to be regarded as 'sports', whose characteristics would in turn be 'transmissible by heredity', as animal and 
plant breeders well knew (Galton and Schuster, 1906: xlii). De Candolle, on the basis of a study (1885) of the social backgrounds of over 300 scientists who were foreign members of European scientific academies - i.e. who had gained international recognition - challenged Galton's almost exclusive emphasis on heredity. While accepting that scientific excellence did have some tendency to run in families, he pointed to the part played by 'family traditions', and stressed that the number of those attaining such excellence was strongly conditioned by national cultural and institutional environments that favoured or disfavoured the promotion of scientific ability.

In this regard, Galton came to agree with de Candolle on at least one point: ${ }^{1}$ the importance of the character and quality of national educational systems. Education in English 'public schools' and at Oxford and Cambridge, Galton maintained, was 'conducted in the interests of the clergy' and was strongly opposed to science. And although this 'gigantic monopoly' of the clergy was slowly yielding, a notable contrast remained with Scotland, where schools and universities were far more conducive to the development of 'a taste for science' (Galton, 1874: 259-60).

In the earlier twentieth century, interest in, and the study of, scientific elites became increasingly centred in the United States, and with a changing focus. Pioneering work of influence was that of the German-trained psychologist, McKeen Cattell (see esp., 1915). Cattell thought that the issue of the relative importance of heredity and environment in scientific ability was misconceived: 'it is like asking whether the extension of a spiral spring is due to the spring or the force applied to it. Some springs cannot be extended by a foot by any force; no

\footnotetext{
${ }^{1}$ On correspondence between Galton and de Candolle, see Fancher (1983) and Gillham (2001: 187-92).
} 
spring can be extended without force' (1915: 6). Cattell's main concern was with how far in the US scientific potential was being adequately exploited in the national interest. He established a list of 1,154 'leading scientific men' in the US, based on the rankings of others in their fields, and sent these men a questionnaire dealing with various aspects of their families of origin. Analysing data from the 975 completed questionnaires that were returned to him, he found that the American scientific elite was predominantly recruited from 'the professional classes' - from the sons (daughters did not figure) of physicians, lawyers, clergy and teachers. Far fewer came from families in manufacturing and trade or from farm families, fewer still from the families of skilled workers, and none at all from the families of domestic servants and unskilled labourers. Overall, the professional classes contributed, in proportion to their numbers in the American population, fourteen times more leading scientists than did all other classes together. Cattell concluded (1915: 8) that while the number of individuals 'capable of exhibiting genius is limited', it was evident that 'many of them are lost through lack of opportunity', and he underlined the damaging consequences for national economic and social development and prestige.

In what was essentially a follow-up study to Cattell's, Stephen Visher (1947), a social geographer, exploited the American Men of Science directory, which had taken over Cattell's method of identifying the leaders in a field. He focused the 2607 scientists who were thus 'starred' in successive editions of the directory from 1903 to 1943, and as well as accumulating published biographical material on these individuals, sent a questionnaire, similar to Cattell's, to the 1443 who were still alive, obtaining responses from 905. Visher's analyses of this body of data led to results that he regarded as disappointing so far as the recruitment of the scientific elite was concerned. He found little change in the situation described by Cattell. The children 
of professionals, and especially of professionals living in larger urban areas, continued to be quite disproportionately represented among leading scientists, while there was little increase in the proportion coming from the broadly defined working class.

In Britain, the interest in the scientific elite shown by Galton was not sustained. So far as we are aware, it was not until a study by Choobbasti (2007) that any research at all comparable to that of Cattell and Visher was undertaken. ${ }^{2}$ In treating the scientific elite as being constituted by Fellows of the Royal Society, Choobasti's study could be regarded as a direct precursor of that on which we here report. It has, however, major limitations. Choobbasti invited all current Fellows whose email addresses were available on the Society's website as of $2005-525$ in total - to complete a web-based questionnaire relating to their social backgrounds. Unfortunately, after two follow-ups, still only 102 Fellows had responded, and since at the time rather less than half of all Fellows provided an email address, it has to be reckoned that Choobbasti obtained information on less than $10 \%$ of his target population. Using the Registrar-General's Social Classes as a basis for analysis - despite this categorisation being for some time outmoded - Choobbasti felt able to claim (2007: 142) that 'a remarkable proportion of intergenerational mobility' was revealed in that $65 \%$ of Fellows' fathers did not have professional occupations.

In our own research, we do wish, eventually, to take up the issues raised in this earlier work of the extent to which social 'skews' in the composition of the scientific elite reflect inequalities of opportunity in accessing the elite, and thus a potential wastage of talent. However, as we

\footnotetext{
2 The papers of Moulin (1955) and Berry (1981) deal with aspects of the social backgrounds of Nobel laureates but are very restricted both in the amount of information provided and in the extent of the analyses that are undertaken. Zuckerman's (1977) study of Nobel laureates who worked in the US is far superior.
} 
have previously argued (Bukodi and Goldthorpe, forthcoming), in addressing such issues, in the case of any elite, simply comparing distributions of its members' social origins or of their type of education with distributions estimated for national populations at large, although a common practice, is unduly limited. Comparisons need also to be made with distributions in the 'pool' from which elite members are generally drawn; and how far skews result from the processes of selection or election from the pool and how far from the social character of the pool itself is a matter of evident importance.

In the present paper, we take as being of interest in themselves, and as prior to other concerns, questions limited to aspects of the social composition of the British scientific elite, as represented by Fellows of the Royal Society: i.e. questions of the extent to which this composition has changed over time and also of the extent to which it may vary by field of research. The composition and, in particular, the degree of social homogeneity of elites has of late attracted growing attention in regard to possible problems of stasis, 'group think' and 'cultural disconnect' in elite outlook and policy where social and cultural diversity is low. In the British case, see on the governmental elite, King and Crewe (2012) and on elites more generally, Social Mobility Commission (2019). Critical comment has in fact arisen (Røstvik and Fyfe, 2018) in regard to the Royal Society itself, over its difficulties in moving on from being a 'gentlemanly space' - or more caustically 'a musty old boys club' - in which an ethos of gentlemanly conduct proved, if only inadvertently, to be in various respects damaging to women scientists, both within and outside of the Society.

Furthermore, starting out from questions of homogeneity serves to reveal issues in the study of elites that have so far been unduly neglected. In particular, the connection between the 
homogeneity of elites and the openness of access to them can be shown to be more complex than is often recognised.

\section{THE ROYAL SOCIETY}

The Royal Society had its origins in an 'invisible college' of 'natural philosophers' who began meeting in Oxford and London in the late 1650s. At a meeting in 1660, addressed by Sir Christopher Wren, a formal society was established and in 1662, under the patronage of King Charles II, this became known as The Royal Society of London for Improving Natural Knowledge. Onwards from the founding Fellows, the Society has always been maintained through the election of new Fellows by existing Fellows or, in other words, is self-replicating. During the eighteenth century, the criteria for election became lax and many men were elected who were political or other public figures rather than practising scientists. Major reforms took place in 1847 aimed at remedying this situation (H.G.L., 1938; Collins, 2016). Since then election procedures have become increasingly stringent, with the specific aim of giving recognition to those who 'have made a substantial contribution to the improvement of natural knowledge, including mathematics, engineering science and medical science'. ${ }^{3}$ The maximum number who could be elected as Fellows from the UK, and later from the Empire or the Commonwealth, in any one year was limited to 15 in 1847, rose to 17 in 1930, to 20 in 1937, to 25 in 1945, and following further regular increments now stands at 52 (for further details on numbers of elections after 1945 see Appendix 1). In addition to 'ordinary' Fellows, Foreign Members were elected from an early stage, so were what are now known as Honorary Fellows - persons who

\footnotetext{
${ }^{3}$ For further details on the election of Fellows, see http://royalsociety.org/fellows/elections.
} 
have brought 'benefits to science' other than through outstanding research - and also Royal Fellows drawn from the UK Royal Family. From the foundation of the Society, over 8,000 individuals have been elected as Fellows in one category or another and the total present membership stands at around 1,700.

Our target population of Fellows is, however, those who came to form the UK scientific elite from the end of World War II. We take this to include Fellows born from 1900 onwards, whether now deceased or still living. ${ }^{4}$ But we exclude from consideration Foreign Members and also Honorary and Royal Fellows, all deceased Fellows whose last employment prior to retirement was not in the UK, ${ }^{5}$ all living Fellows whose most recent employment was not in the UK, and all Fellows who, from the information available to us, would appear to have spent significantly more of their research careers outside of rather than within the UK.

Thus defined, our target population numbered 2112 Fellows. We did not then seek to study only a sample of these Fellows but, ideally, the totality, with the eventual aim of producing a prosopography - a collective biography - of these Fellows in regard to characteristics of interest to us (on prosopographical research in general, see Stone, 1971, Keats-Rohan, 2007). The characteristics on which we focus, and in terms of which we aim to discuss the composition of the Fellowship, are those of the parental social class and type of secondary schooling of Fellows, which we treat in the present paper, and of their university education and subsequent academic careers, which we will take up in a forthcoming companion paper.

\footnotetext{
${ }^{4}$ In 1940, the average age of Fellows at election was 44 but has been steadily rising. By 2019 it had reached 58 (Royal Society, 2019)

${ }^{5}$ That is, prior to retirement from positions involving a commitment to scientific research.
} 
Other characteristics in terms of which the composition of the Fellowship could obviously be discussed are those of gender and ethnicity. However, these have of late been of great concern within the Royal Society, and through the activities of its Diversity Committee the relevant facts have been well established (see e.g. Royal Society, 2019). While over recent years women have made up between a fifth and a quarter of all elected (see further Appendix 1), they still represent only around $10 \%$ of the total Fellowship. Fellows from ethnic minorities constitute, at a best estimate, around 5\% of the total Fellowship. In other words, as regards gender and ethnicity, it can be said that Fellows of the Royal Society are highly homogenous as male and white.

DATA

We have sought to obtain information on the parental class and the schooling of the 2112 Fellows in our target population in a variety of ways. For deceased Fellows, we rely mainly on the Royal Society's excellent Memoirs, which in the large majority of cases include relevant details. But, where necessary, we also resort to the Dictionary of National Biography and to obituaries and other material available on the web. For living Fellows, our information comes mainly from a web-based questionnaire that was sent to all living Fellows in our target population in late 2020 , and to which we received a response rate of almost $70 \% .{ }^{6}$ However, especially in regard to schooling, we also draw on Who's Who and Debrett's People of Today and again on web material. Table 1 shows the extent to which we were able to acquire relevant

\footnotetext{
${ }^{6}$ On account of some failures of communication, the Royal Society was not fully aware of our research when the questionnaires were first sent out. Shortly afterwards, however, and before the first 'reminder' to non-respondents, all Fellows were informed that the Society endorsed our work, which undoubtedly helped to raise the response rate. We are most grateful to the Society and to its officers for their very helpful co-operation.
} 
information and the sources of this information across the seven 10-year birth cohorts that we distinguish.

[Table 1]

As is evident, we do have problems of missing data, most notably with living Fellows in the later birth cohorts, and as a result primarily of the $30 \%$ non-response to our survey. Overall, though, we still have full information on 1691 Fellows, representing an 80\% coverage of our target population - a result that compares very favourably with those of earlier studies of elites of any kind, and especially in regard to social origins (see further Bukodi and Goldthorpe, forthcoming). In addition, we report in Appendix 2 results from modelling in which we investigate how far differences arise between living and deceased Fellows in the probabilities of their coming from particular class backgrounds or of their type of secondary schooling, while controlling for birth cohort. As can be seen, the differences are small.

In view of the foregoing, we believe it defensible to take the Fellows on whom we do have full information as being representative of our target population with the possibility of only very minor, if any, biases occurring. Where we resort to statistical modelling we do not therefore apply tests of statistical significance. We treat the results as being descriptive of our target population and focus on the pattern and the size of the coefficients returned.

Of our target population of 2112 Fellows, 155 were women and full information was obtained on 125 of these - a similar coverage as with men. But in view of this small number, we do not in the present paper consider gender differences except in occasional notes. 


\section{SOCIAL ORIGINS OF FELLOWS}

As earlier indicated, we treat the social origins of Fellows according to the social class of their parents - that is, at the time of the Fellow's adolescence, ideally at around age $14-15 .^{7}$ For this purpose, we resort to a modified version of the National Statistics Socio-economic Classification (Office of National Statistics, 2005), as shown in Table 2. As can be seen, a division is made within NS-SEC Classes 1 and 2 between their professional and managerial components, while Classes 3 and 5 and Classes 6 and 7 are collapsed.

\section{[Table 2]}

In the upper panel of Figure 1, we show the distributions of Fellows by parental class and by birth cohort. What is most immediately apparent is that in all birth cohorts close to, or over, $30 \%$ of Fellows come from higher professional families, with this proportion rising to over $40 \%$ for the most recent cohort. A notable contrast is that, except in the first cohort, a much smaller proportion of Fellows had fathers (or, very rarely, mothers) who were large employers or higher managers. In the later cohorts this proportion is not much above, or less than, $10 \%{ }^{8}$ Similarly, the proportion of Fellows coming from lower professional backgrounds is always greater than the proportion coming from lower managerial backgrounds, and this difference

\footnotetext{
${ }^{7}$ Where we have information - i.e. on occupation and employment status - that allow us to establish the class positions of a Fellow's father and mother and these differ, we apply the 'dominance' method (Erikson (1984). In fact, given the historical period covered, many mothers were not in employment and those that were typically held class positions that were at the same or a lower hierarchical level within NS-SEC than those of their husbands. Thus, in effect, parental class does in the very large majority of cases refer to father's class.

8 The first cohort is distinctive in that $10 \%$ of Fellows were the sons of large employers - i.e. of employers with more than 25 employees - mostly the owners of family businesses who were themselves involved in their managements. For all later cohorts this is the case with only $2-3 \%$ of Fellows.
} 
again becomes more marked across the cohorts. Thus in the most recent cohort, close to twothirds of all Fellows are in fact from professional backgrounds as compared with only a fifth from managerial backgrounds.

[Figure 1]

In this regard, our findings must then call into doubt Choobbasti's claim that, as of 2005, 65\% of Fellows of the Royal Society came from other than professional backgrounds. However, of greater interest is that our results are much in line with those of the studies of the American scientific elite in the first half of the twentieth century as discussed above. We too find that a division runs through more advantaged social classes such that professional families are clearly more productive of outstanding scientists than are managerial families - and indeed to an apparently increasing extent. ${ }^{9}$

One other feature of Figure 1 that is of evident interest is the changing proportion of Fellows of less advantaged social origins: that is, who were the children of small employers and own account workers - mainly tradesmen, shopkeepers and café, garage and other small proprietors - or of wage-earning working-class parents. It can be seen that this proportion rises somewhat from the first cohort to over $25 \%$ for the next three cohorts, being thus - a rather striking fact - higher than the proportion coming from all managerial backgrounds. However, it then falls away to less than $9 \%$ in the most recent cohort, and with this cohort the proportion

\footnotetext{
${ }^{9}$ More recent American work by Xie (1992) confirms that direct parental class effects on the probability of becoming a scientist do not exhibit 'a systematic pattern along the socioeconomic scale' (1992: 271). Controlling for education, the children of professionals have the highest probability of becoming scientists but then followed by the children of manual wage-workers - with the children of managers having a clearly lower probability.
} 
of Fellows coming from working-class backgrounds, which for the 1930-39 cohort was almost $18 \%$, is now more or less negligible. ${ }^{10}$

What then do these distributions imply for the degree of homogeneity of Fellows in terms of their social origins? We use the index of homogeneity $(\mathrm{IH})$ introduced by Blau and Duncan (1967: 52-3). The percentage distributions shown in Figure 1 can be treated as the set of probabilities of individuals in each birth cohort coming from each class of origin, and the squares of these probabilities can then be summed so as to give the probability that any two individuals chosen at random within a cohort will be of the same class of origin. The maximum value the index can take is 1 , where all individuals have the same class origin, and the minimum value - indicating the greatest possible degree of heterogeneity - is the reciprocal of the number of parental classes distinguished: in our case $1 / 7=0.14$.

In the lower panel of Figure 1 we show the $\mathrm{IH}$ for each cohort. The degree of homogeneity across the cohorts proves overall to be fairly low. It can be seen that the $\mathrm{IH}$ falls somewhat between the first and second cohorts and then remains below 0.20 for Fellows in the next four cohorts before rising so as to reach 0.25 in the most recent cohort. In other words, with the seven classes we distinguish, there is never more than a $25 \%$ probability that any two Fellows in the same cohort, meeting by chance, would find that they were of the same class origins. The increase in the $\mathrm{IH}$ in the last two cohorts is clearly associated with the rising proportion of Fellows from professional backgrounds and the falling proportion from either managerial or other, less advantaged, backgrounds.

\footnotetext{
${ }^{10}$ Overall, the distribution of the class origins of the 125 women Fellows on whom we have information could be regarded as a somewhat exaggerated version of that described in the text: $41 \%$ come from higher professional families and a further $18 \%$ from lower professional families but only $2 \%-$ i.e. just three individuals - from working-class families.
} 
Changes in the composition of any collectivity in terms of the class origins of its members will of course be conditioned by the changing distribution of positions within the class structure as it evolves. In the present case, we can take account of this, if with some limitations, by drawing on data from earlier sociological research to determine the changing class distributions of fathers, or other heads of household, in the population at large. The limitations are that we have no relevant data for the earliest birth cohort of Fellows, that the data we do have do not allow us to make the distinction between the professional and managerial components of NSSEC Classes 1 and 2, and that they relate to Britain rather than to the UK.

In Figure 2, we compare, for the last six cohorts of Fellows, their parental class distributions with our best estimates of the class distributions of fathers or other heads of household in the population at large at around the time of the Fellows' adolescence. And for each comparison we report the Index of Dissimilarity (ID) - i.e. the proportion of cases that would have to be reallocated in order to make the two distributions identical - and also the corresponding IHs.

[Figure 2]

As might be expected, the dissimilarities between the pairs of distributions are wide. IDs are always above $50 \%$, and the main source of this lies in the far greater discrepancy between the number of Fellows originating in NS-SEC Class 1 - predominantly, we know, in its professional component - and in NS-SEC Classes 6 and 7 than is the case with individuals in the population at large. Moreover, the dissimilarities clearly widen with the last two birth cohorts. Correspondingly, in turning to the $\mathrm{IHs}$ - here calculated on the basis of five rather than as previously seven classes - we find that while for the earlier cohorts covered, homogeneity in terms of class origins could be regarded as being greater in the population at large than among Fellows, with the most recent cohort this situation is reversed. 
What has to be recognised here is that the lower degree of homogeneity among Fellows in the earlier cohorts is largely the result of their disproportionate recruitment from more advantaged class backgrounds. Had they been recruited to an equal extent from all classes, they would have been far more homogenous in that the majority would have come from Class 6 or 7 -or, that is, working-class - backgrounds. The trend of IHs reflects the fact that while in the population generally the proportion of individuals of Class 1 origin has been steadily increasing and that of individuals of Class 6 and 7 origins decreasing, with Fellows these shifts have been yet more pronounced.

As regards the social origins of Fellows, one other question of interest is how far they come from families where at least one parent was in an occupations that, whatever its class location, involved some degree of scientific, technical, engineering or mathematical (STEM) knowledge and expertise. ${ }^{11}$ Relevant results are shown in Figure 3.

[Figure 3]

What chiefly stands out from this figure is the sharp rise in the two most recent cohorts of the proportion of Fellows - up to almost a third - who have a parent in what could be regarded as a STEM occupation, the majority being in fact professional ones. It is further shown that while with the first cohort the proportion of professional parents in STEM occupations amounted to less than half of all professional parents, in subsequent cohorts this proportion, though fluctuating somewhat, is clearly higher, while the proportion of Fellows coming from professional families in general increases. One may then say that insofar as the British scientific elite is recruited from more advantaged social classes, it is not only the case that this

\footnotetext{
${ }^{11}$ For reasons given in $\mathrm{n} .7$, the parent will in the large majority of cases be the father.
} 
recruitment comes far more from the professional than from the managerial component of these classes. It is also the case that it comes more from what may be regarded as STEM families rather than from other families within the professional component.

Finally, it may be asked whether what holds good for the social class origins of Fellows as a whole applies equally to Fellows in the ten different Subject Areas (SAs) - or fields of scientific research - that the Society identifies, full details of which are given in Appendix $3 .{ }^{12}$

In Table 3 we show the distributions by parental class of Fellows in the SAs in which, according to their present positions and titles, their research would appear to fall. What is most immediately apparent is the contrast that arises between the class of origins of the chemists in SA 3 and of those working in the various biological fields covered by SAs 7-10. Only a little over $20 \%$ of the chemists come from higher professional backgrounds and $15 \%$ from workingclass backgrounds, while a clearly higher proportion of Fellows in SAs 7-10 are of higher professional origins and, in each case, less than $10 \%$ are of working-class origins. Chemists have the lowest IH of 0.15 - close to the minimum of 0.14 with the seven classes distinguished.

\section{[Table 3]}

To take the analysis of this situation further, we run a multinomial logit model to show the relative importance of class origins on the probabilities of Fellows being found in different research fields, with birth cohort also included. To preserve adequate numbers, we collapse

\footnotetext{
12 Differences in composition across SAs have previously been discussed in relation to gender. Mason (1992: 214) observed that over $80 \%$ of women elected as Fellows over the years from their first election worked in the biological sciences. We can add that of the 125 female Fellows in our target population on whom we have information, $70 \%$ are in the biological sciences as compared with only $43 \%$ of the 1566 male Fellows.
} 
SAs to four, in such a way as to separate out SA3 and SAs 7-10, and cohorts to three. Results are given in Table 4.

[Table 4]

The cohort effects indicate some increase over time in the probability of Fellows being found in SA 6, which covers research fields that have been in expansion. As regards parental class effects, the most notable results are the following. Being of any other class origin than higher professional increases the probability of a Fellow being a chemist rather than working in other research fields, and by as much as 9 percentage points in the case of being of working-class origins. In contrast, being of any other class origin than higher professional reduces the probability of a Fellow working in SAs 7-10 rather than being found in other research fields, and by as much as 20 percentage points in the case of being of working-class origins.

In Appendix 4, we show absolute probabilities of being in particular research fields for Fellows from different class backgrounds, estimated from a model in which an interaction term between parental class and birth cohort is also included. It can be seen that while differences in class origin effects on the probabilities of Fellows being found in SAs 7-10 tend to diminish across the cohorts, no such change is apparent in the probabilities of being found as a chemist in SA 3.

We return to variation among Fellows in different fields of research in the next section on Fellows' schooling. But a general point can already be made: that detailed analyses of elite composition may point to differences in the recruitment processes that operate within different segments of an elite. In other words, disaggregation may be important in this regard, 
just as we have shown that it is in distinguishing between different components of the classes from which elite members are chiefly drawn.

\section{SCHOOLING OF FELLOWS}

Analysing the changing composition of Fellows of the Royal Society by the type of secondary school they attended is problematic in several respects. To begin with, in all cohorts a nonnegligible proportion of Fellows, always over $10 \%$ but rising to around $20 \%$ in the two latest cohorts, attended schools outside of the UK. In the analyses that follow, we leave these Fellows out of account. ${ }^{13}$ However, with Fellows whose secondary education was within the UK the difficulty remains of forming a consistent categorisation of schools as a result of historical changes in the system of secondary education (see Mandler, 2020: ch. 2). In regard to the types of secondary school introduced in Figure 4, the following points need to be made. First, although the official designation of 'direct grant grammar schools', which we adhere to, only existed from 1945 to 1976, many grammar schools were in effect 'direct grant' from early in the twentieth century. In return for state support, they accepted some proportion of 'scholarship' pupils from state elementary schools while the majority of their pupils remained fee-paying or supported by their own scholarships. Second, up to 1945 'maintained' grammar schools, under the control of local educational authorities, were in many cases allowed to take in some proportion of fee-paying pupils who had not sought or had failed to gain scholarships.

\footnotetext{
${ }^{13}$ Many of these Fellows in earlier cohorts were refugees - 'Hitler's gift' to British science. In later cohorts it is the increasing globalisation of science that is chiefly reflected. It may be noted that less than a quarter of all Fellows whose secondary schooling was outside of the UK attended private schools.
} 
And, third, some private schools did offer their own scholarships or a number of 'free places' in return for a degree of state support. ${ }^{14}$

Discussion of Figure 4 has therefore to centre on the type of school attended per se rather than on whether or not a Fellow's secondary education was on a fee-paying basis. The main point that then emerges from the figure is that of those Fellows whose secondary education was in the UK, the proportion who attended private schools shows little directional change, being, in each cohort alike, from around two-fifths up to almost a half. ${ }^{15}$ This can be set against the fact that, over the period covered, only between $6 \%$ and $8 \%$ of all children in the UK went to private schools. One change that is, however, apparent is that, with the two most recent cohorts, Fellows educated in the private sector are more likely than those in earlier cohorts to have attended day schools rather than boarding schools - this probably being, in part at least, the result of many former direct grant grammar schools opting to become private. With Fellows educated in the state sector, the relative importance of different types of school across the cohorts largely reflects changes in the educational system, as is seen most notably in the rising proportion attending comprehensive rather than grammar schools from the fifth cohort onwards. ${ }^{16}$

[Figure 4]

\footnotetext{
${ }^{14}$ It has also to be noted that over the period we cover, the status of particular schools could change. We have attempted in the case of each Fellow to categorise the school he or she attended according to its status at the time of their attendance.

${ }^{15}$ Of the 125 women Fellows included, 45\% were privately educated.

${ }^{16}$ It has been suggested to us that the decline in the proportion of Fellows coming from working-class origins may be the result of the introduction of comprehensive secondary education. However, this decline is already very evident in the 1950-59 birth cohort in which, as can be seen from Figure 4, Fellows educated in the state sector still predominantly attended grammar schools.
} 
Reverting to those Fellows who were educated in the private sector, further points of interest arise in the case of those who are the alumni of the Clarendon schools. These are the nine schools whose finances and management were investigated by the Clarendon Commission, 1861-64, in view of what was taken to be their national importance as the 'chief nurseries' for 'every profession and career' in the country - and the role of which in the formation of British elites is still much discussed. ${ }^{17}$

First, in Table 5, we show these nine schools ranked according to their contribution to the Fellowship of the Royal Society over the period that concerns us. Three schools - St Paul's, Winchester and Westminster - stand out, accounting in fact for over half of all Fellows who went to Clarendon schools. In contrast, the contribution of Eton is only modest and that of Harrow smaller still. With some of these 'leading schools', as the Clarendon Commission described them, it might then seem that Galton's strictures on the failure of the 'public schools' to develop 'a taste for science' retained their relevance well into the twentieth century. And the teaching of science in these schools in general would appear to have been widely regarded as inferior to that provided in grammar schools (Turner, 2015: 173-5). ${ }^{18}$

[Table 5]

\footnotetext{
${ }^{17}$ The Clarendon schools took only boys until, from the 1970s, Westminster and Charterhouse and then later Shrewsbury began to accept girls into their sixth forms, while Rugby became fully co-educational in 1992. However, those Fellows of the Royal Society with whom we are concerned who attended such schools were all male.

${ }^{18}$ For example, at Eton, in 1936, there were 39 classics masters, compared with only nine in science. After 1945, however, there was some notable changes in the curriculum. Some major boarding schools introduced a so-called 'modern side' that gave more emphasis to science, applied mathematics and modern languages (McKibbin, 1998: 244-245).
} 
Second, we may place our findings in this regard in the context of a recent analysis by Reeves et al. (2017) of the schooling of British elites in general, with elite membership being determined by appearance in Who's Who. In Figure 5, we include Fellows of the Royal Society in a graph derived from Reeves et al. (2017: Appendix Part F) which shows the changing proportions of those who came from Clarendon schools in seven other elites. It can be seen that in the earliest cohort the Fellows, along with the educational elite (in which Reeves et al. include scientists), have one of the lowest proportions of Clarendon alumni, at under $10 \%$ - in marked contrast with the military and legal elites especially. However, while with the Fellows little change in this proportion occurs across the cohorts (cf. Figure 4 above), with most of the other elites it tends to decline, in some cases sharply, so that by the latest cohort the Fellows are in a middling position within a much narrower range of variation. Reeves et al. conclude (2017: 14) that the ability of Clarendon schools to deliver elite destinations has been 'meaningfully altered' as a result of reforms furthering 'the democratization and standardization of education'. But, if this is so, the question arises of why these reforms should have had so little apparent impact in the case of the scientific elite. Reeves et al. suggest (2017: 21) that Clarendon schools are finding particular difficulty in promoting elite access for their 'educationally less meritorious alumni' - and this might be thought unlikely to apply to those having the potential to become Fellows of the Royal Society. But other explanations, including ones involving data comparability, may also be involved. ${ }^{19}$

\footnotetext{
${ }^{19}$ For example, problems may arise with using Who's Who as a source of information on elites. Only around a half of those included are automatically selected on account of their holding specific positions - though the full list of these positions is not available (Reeves et al., 2017: Appendix, Part A) - and the remainder are selected by a board of advisors according to criteria that are not known and that could, presumably, change over time. Further, while Reeves et al. report (Appendix Part B) a coverage of the 'educational field' of their Who's Who entrants that generally rises across cohorts, to reach around $97 \%$, it appears that this relates to cases where any information on education was obtained - as, say, on university education but not on secondary schooling. Insofar as we have ourselves resorted to Who's
} 
[Figure 5]

We turn next to the relationship between Fellows' schooling and their social origins. Table 6 provides the basic information. As regards schooling in the private rather than in the state sector, clear lines of class division are apparent. Over two-thirds of Fellows of higher professional and higher managerial origins went to private secondary schools, as compared with less than two-fifths of those of lower professional and managerial origins, and a smaller proportion still with those originating in less advantaged classes. In this case, neither the professional/managerial distinction nor that between STEM and non-STEM professional families is of any great consequence. However, it is at the same time important to note that still a sizable minority of all Fellows of higher professional and managerial origins did attend state secondary schools of one kind or another. The point we have previously made (Bukodi and Goldthorpe, forthcoming) of the dangers of taking type of secondary school as a proxy for social origins - as, for example, in the Social Mobility Commission's (2019) study of elites - is thus underlined. In the present case, this would lead to a serious underestimation of the extent to which Fellows of the Royal Society do in fact come from more advantaged class backgrounds.

Fellows from self-employed or working-class families largely attended grammar or, later, comprehensive schools but a further point of interest is the non-negligible proportion whose schools fall into the 'other' category. Apart from some religious schools, these are, for those in earlier cohorts, mostly the old 'central schools', established after 1918 to provide secondary

Who, we find that while information on entrants' university education is generally available, information on their secondary schooling is quite often missing and to an increasing extent across cohorts. For our latest cohort of Fellows, such information is missing in as much as $60 \%$ of cases. 
education for some of those who failed to gain entry to grammar schools, or, for those in later cohorts, technical schools or colleges.

[Table 6]

In Table 7, we again resort to logit models to analyse the relation between parental class, collapsed to five levels and type of school attended, with birth cohort, collapsed to three, also being included. The results serve chiefly to confirm and quantify what has already been indicated. The cohort effects bring out some general tendency for private schooling to decline - on account of a decline in boarding school rather than day school attendance. The parental class effects then show the lower probabilities of Fellows of less advantaged class origins having attended private rather than state schools - falling, in the case of the least advantaged, to almost 50 percentage points lower than with Fellows of higher professional origins. Among Fellows privately educated, differences in class origin effects are most marked as regards attendance at Clarendon or other boarding schools. But also of interest is that Fellows from higher managerial backgrounds have a lower probability than those from higher professional backgrounds of attending private day schools rather than boarding schools.

[Table 7]

In Appendix 5, we show estimated probabilities of attending different types of school from a model in which an interaction term between birth cohort and parental class is included. Little change is apparent across the cohorts, except that the tendency of Fellows of higher professional origins to increasingly attend private day rather than boarding schools can be seen to begin with those born after 1949 and to lead to clearly wider class differences in this regard. 
Finally, with Fellows' schooling as with their class origins, we take up the question of whether differences exist according to their field of research. The results presented in Table 8 are much on lines that might be expected, given the strong association already established between Fellows' class origins and their type of secondary schooling. Only a fifth of the chemists in SA 3 attended private boarding schools and around three-fifths went to grammar, comprehensive or other state schools, while with Fellows in SAs 7-10 from a third to over two-fifths attended private boarding schools and, in all cases, less than half went to state schools.

[Table 8]

In Table 9 results are shown from two multinomial logit models of the effects of class origins and of private rather than a state secondary education on the probabilities of Fellows being found in different research fields, with cohort also included as a control variable. Model 1 is the same as that of Table 4. The results reported are somewhat different, since we are now considering only those Fellows whose secondary education was in the UK, but they are on much the same pattern as previously. It is the contrasting effects of class origins on the relative probabilities of Fellows working in chemistry and in the fields covered by SAs 7-10 that remain of chief interest. From Model 2 it can then be seen that, when type of schooling is introduced, the effects of coming from other than higher professional origins, positive on the probabilities of being a chemist but negative on the probabilities of working in SAs 7-10, are both reduced. However, the changes are rather slight, and the indication is that in accounting for the differing class origin effects on Fellows being found in different research fields, other factors than schooling are of main importance and call for further investigation. ${ }^{20}$

\footnotetext{
${ }^{20}$ Insofar as an effect of schooling exists, the fact that chemists are less likely then Fellows in other fields to have been privately educated, regardless of their class origins, suggests that chemistry may have had
} 
[Table 9]

Further, in Appendix 6 we show absolute probabilities of being in particular research fields for Fellows of different class origins and with different types of schooling, estimated from a model in which an interaction term between these two variables is included. What is suggested by the general pattern of the results reported is that their effects are essentially additive: i.e. there is no systematic evidence of type of school attended either strongly reinforcing or offsetting the effect of parental class on field of research.

\section{CONCLUSIONS}

We have examined the social composition of the UK scientific elite, as represented by Fellows of the Royal Society, in terms of Fellows' class origins and type of schooling, and have traced out the nature of changes in this composition over ten birth cohorts extending back to the start of the last century.

As regards class origins, our main finding is that, in line with previous American research, elite scientists come predominantly from professional families - and increasingly so. The proportion coming from business and managerial families is clearly lower, and among Fellows born between 1910 and 1939, was actually lower than the proportion coming from the families of small employers, own account workers and manual wage-workers. A point of more general

a higher status and have been better taught in state, especially grammar, schools, than in many private schools, and even after science became a more important part of their curriculum. Turner $(2015,175)$ tells of a 'public school' headmaster writing to a newly appointed mathematics teacher that 'it would be an advantage if you could teach some chemistry' - though later explaining, after the teacher had prepared himself, that he had really meant physics. To him, it was all just 'science', and in his school sixth-formers studying it were 'the barbarians' who were not allowed to sit with the classicists at lunch. 
significance is thus brought out. It should not be supposed - as seems often to be the case that recruitment to elites is entirely structured according to hierarchical class divisions. What can be thought of as 'horizontal' divisions existing within classes, and creating different occupationally-based components, may also be of importance in regard to elite recruitment.

The skewed pattern of recruitment that prevailed over earlier cohorts actually led to a quite low level of homogeneity among Fellows of the Royal Society so far as their class backgrounds were concerned. Fellows were in fact in this regard more heterogeneous in their composition than was the national population. However, a process of increasing homogeneity is evident with the two latest cohorts that we distinguish. This results from the increasing proportion of Fellows coming from professional families, as the proportion of such families in the population at large also increases, while a decreasing proportion of Fellows come from less advantaged families - and especially from working-class families - as these families form a decreasing proportion of the population. Whereas previously social skewness in recruitment made for heterogeneity among the Fellowship, this skewness now comes to have the reverse effect.

A further source of increasing homogeneity in the social origins of Fellows that we can observe lies in the greater number in the two latest cohorts who have a parent, usually the father, in a STEM occupation, most often a professional one. If a trend in this direction were to continue, the possibility could be envisaged - through the spread of 'family traditions' in science as emphasised by de Candolle - of STEM families becoming a kind of recruitment caste for scientists, and including those destined to achieve eminence.

At the same time, though, we have found that parental class has an effect on the probability of Fellows working in different research fields. Being of any other class origin than higher professional increases the relative probability of a Fellow being a chemist, while decreasing 
that of a Fellow working in a range of biological sciences - although this latter effect would appear to be weakening.

Turning to Fellows' secondary schooling, our central finding is that, among those whose schooling was in the UK, a very high proportion, in comparison with children in the population at large, attended private schools - between two-fifths and a half across cohorts - although some shift is evident away from boarding schools to day schools. In the light of available research, the proportion of Fellows who attended Clarendon schools would appear to be relatively low as compared with that found among the members of a range of other elites - at something a little below $10 \%$ - but this proportion also remains quite constant. Three Clarendon schools, St Paul's, Winchester and Westminster, are of main importance in contributing to the scientific elite.

As regards the relationship between Fellows' schooling and their class origins, what we find is in one way quite unsurprising. Those Fellows whose parents were in the most advantaged, higher professional and managerial, class positions, as covered by NS-SEC Class 1, are far more likely than others to have been privately educated, while Fellows coming from working-class families have been overwhelmingly educated in the state sector. But two further points have to be noted. First, more than a fifth of all Fellows coming from higher professional and managerial families did attend state schools, thus showing that to take type of schooling as an indicator of class origins can be seriously misleading. Second, the fact that there is little difference in the distributions of type of school attended as between Fellows coming from professional and managerial families is of some significance in relation to the question of why the former are clearly the more important in the composition of the scientific elite. It could be that professional parents, and especially those in STEM occupations, tend to be more 
concerned to send their children to schools, whether private or state, that have a good reputation for science teaching. But the further possibility is that the influence of schools is in general less than that of family in creating an interest in science and the motivation to pursue a scientific career.

The relatively modest influence of schooling as compared with that of family is also suggested in regard to Fellows' fields of research. We find that while type of a secondary school attended does modify somewhat the effects of parental class on the relative probabilities of Fellows working in different fields, the difference made is not great. What is more generally indicated here is that pathways from families of origin into an elite may not be quite uniform but may vary in relation to different segments of the elite in ways that require further investigation.

In sum, the social composition of the UK scientific elite, as represented by Fellows of the Royal Society, shows important elements of both long-term change and constancy. This elite is now becoming more socially homogenous in that Fellows are increasingly drawn from professional families, and increasingly too from such families in which a parent is in a STEM occupation, while over more recent birth cohorts the number of Fellows who are of working-class origins has shrunk to an almost negligible level. At the same time, what has remained little changed is the relatively high proportion of Fellows who are privately educated, even though boarding school education is in some decline. Taking Fellows' class origins and schooling together, it could be said that they enter into the scientific elite through three main routes: for those of more advantaged class origins, through both private and state education, and for those of less advantaged origins, predominantly through state education, earlier at grammar schools and more recently at comprehensives. However, there is variation in these respects associated with Fellows' fields of research, and we would further expect to find that pathways into the elite 
appear yet more complex when university education, at both undergraduate and postgraduate levels, is taken into account. 


\section{REFERENCES}

Berry, C. (1981). The Nobel scientists and the origins of scientific achievement. British Journal of Sociology, 32, 381-91.

Blau, P. M. and Duncan, O. D. (1967). The American occupational structure. Wiley.

Bukodi, E. and Goldthorpe, J. H. (2021). Elite studies: for a new approach. Political Quarterly, forthcoming.

Cattell, J. M. (1915). Families of American men of science. Popular Science Monthly, 86, 1-8.

Choobbasti, H. J. (2007). The social origins of eminent scientists: a review, comparison and discussion. Research in Social Stratification and Mobility, 25, 233-43.

Collins, P. (2016). The Royal Society and the promotion of science since 1960. Cambridge University Press.

De Candolle, A. (1885). Histoire des sciences et des savants depuis deux siècles. H. Georg.

Erikson, R. (1984). Social class of men, women and families. Sociology, 18, 500-14.

Fancher, R. E. (1983). Alphonse de Candolle, Francis Galton, and the early history of the nature-nurture controversy. Journal of the History of the Behavioural Sciences, 19, 341-52.

Galton, F. (1869). Hereditary genius. Macmillan.

Galton, F. (1874). English men of science: their nature and nurture. Macmillan.

Galton, F. and Schuster, E. (1906). Noteworthy families (modern science). Publications of the Eugenics Record Office, University of London.

Gillham, N. W. (2001). A Life of Sir Francis Galton: from African exploration to the birth of eugenics. Oxford University Press.

H.G.L. (1938). The growth of the Fellowship. Notes and Records of the Royal Society of London, 1, 4048.

Keats-Rohan, K.S.B. (Ed.) (2007). Prosopography approaches and applications: A handbook. Oxford Unit for Prosopographical Research.

King, A. and Crewe, I. (2013). The blunders of our governments. Oneworld publications.

Mandler, P. (2020). The crisis of meritocracy: Britain's transition to mass education since the Second World War. Oxford University Press.

Mason, J. (1992). The admission of the first women to the Royal Society of London. Notes and Records of the Royal Society of London, 46, 279-300.

McKibbin, R. (1998). Classes and Cultures. England 1918-1951. Oxford University Press. 
Moulin, L. (1955). The Nobel prizes for the sciences from 1901-1950: an essay in sociological analysis. British Journal of Sociology, 6, 246-63.

Office for National Statistics (2005). The national statistics socio-economic classification. London: ONS. Reeves, A., Friedman, S., Rahal, C. and Flemmen, M. (2017). The decline and persistence of the old boy: private schools and elite recruitment 1897-2016. American Sociological Review, 82, 1139-66.

Røstvik, C. M. and Fyfe, A. (2018). Ladies, gentlemen, and scientific publication at the Royal Society, 1945-1990. Open Library of the Humanities, 4, 1-40.

Royal Society, (2019). Diversity data report 2019. Royal Society.

Social Mobility Commission (2019). Elitist Britain, 2019. Social Mobility Commission.

Stone, L. (1971). Prosopography. Daedalus, 100, 46-79.

Turner, D. (2015). The old boys: the decline and rise of the public school. Yale University Press.

Visher, S. S. (1947). Scientists starred 1903-1943 in 'American Men of Science'. Johns Hopkins Press.

Xie, Y. (1992). The social origins of scientists in different fields. Research in Social Stratification and Mobility, 11: 259-79.

Zuckerman, H. (1977). Scientific elite: Nobel laureates in the United States. Free Press. 
TABLES \& FIGURES 
TABLE 1: Extent of coverage of target population of Fellows and primary sources of information by birth cohort

\begin{tabular}{|c|c|c|c|c|c|c|c|c|}
\hline & \multicolumn{7}{|c|}{ Birth cohort } & \multirow{2}{*}{ All } \\
\hline & 1900-09 & 1910-19 & $1920-29$ & 1930-39 & $1940-49$ & $1950-59$ & $1960-$ & \\
\hline Initial target population $(\mathrm{N})$ & 278 & 251 & 373 & 321 & 366 & 319 & 204 & 2112 \\
\hline \multicolumn{9}{|l|}{$\%$ of missing information on } \\
\hline parental class & 2.9 & 6.0 & 16.4 & 24.9 & 23.0 & 24.8 & 29.4 & 18.3 \\
\hline type of secondary school & 2.5 & 1.6 & 2.4 & 6.9 & 7.7 & 16.6 & 20.6 & 7.8 \\
\hline either parental class or type of secondary school & 5.0 & 7.2 & 17.2 & 26.2 & 24.3 & 27.6 & 31.4 & 19.9 \\
\hline \multicolumn{9}{|l|}{ Achieved target population } \\
\hline $\mathrm{N}$ & 264 & 233 & 309 & 237 & 277 & 231 & 140 & 1691 \\
\hline$\%$ & 95.0 & 92.8 & 82.8 & 73.8 & 75.7 & 72.4 & 68.6 & 80.1 \\
\hline \multicolumn{9}{|l|}{ Primary source of information on parental class } \\
\hline Who's Who & 0.0 & 0.0 & 1.3 & 3.8 & 5.1 & 3.0 & 5.7 & 2.5 \\
\hline RS Memoirs /DNB & 98.9 & 89.3 & 77.0 & 36.7 & 5.4 & 1.7 & 0.7 & 48.1 \\
\hline Web & 1.1 & 10.3 & 16.8 & 13.1 & 11.2 & 7.8 & 5.7 & 9.9 \\
\hline Survey & 0.0 & 0.4 & 4.9 & 46.4 & 78.3 & 87.5 & 87.9 & 39.5 \\
\hline Total & 100.0 & 100.0 & 100.0 & 100.0 & 100.0 & 100.0 & 100.0 & 100.0 \\
\hline \multicolumn{9}{|c|}{ Primary source of information on type of secondary school } \\
\hline Who's Who & 0.4 & 6.9 & 17.5 & 44.7 & 54.2 & 52.0 & 33.6 & 29.2 \\
\hline Debrett's & 0.0 & 0.0 & 0.0 & 4.6 & 10.5 & 3.9 & 1.4 & 3.0 \\
\hline RS Memoirs/DNB & 98.9 & 88.8 & 75.4 & 34.6 & 5.1 & 1.7 & 0.7 & 47.4 \\
\hline Web & 0.8 & 4.3 & 6.2 & 4.2 & 2.9 & 2.6 & 3.6 & 3.6 \\
\hline Survey & 0.0 & 0.0 & 1.0 & 11.8 & 27.4 & 39.8 & 60.7 & 16.8 \\
\hline Total & 100.0 & 100.0 & 100.0 & 100.0 & 100.0 & 100.0 & 100.0 & 100.0 \\
\hline
\end{tabular}


TABLE 2: Modified version of National Statistics Socio-Economic Classification (NS-SEC)

\begin{tabular}{|c|c|c|}
\hline & NS-SEC & $\begin{array}{l}\text { Modified version and labelling } \\
\text { used }\end{array}$ \\
\hline 1 & $\begin{array}{l}\text { Higher managers, large employers } \\
\text { and higher professionals }\end{array}$ & $\begin{array}{l}\text { Higher professional } \\
\text { Higher managerial }\end{array}$ \\
\hline 2 & $\begin{array}{l}\text { Lower managers, higher supervisors } \\
\text { and lower professionals and higher } \\
\text { technicians }\end{array}$ & $\begin{array}{l}\text { Lower professional } \\
\text { Lower managerial }\end{array}$ \\
\hline 3 & Intermediate, clerical, etc. employees & \\
\hline 5 & Lower supervisors and technicians & \\
\hline 4 & $\begin{array}{l}\text { Small employers and own account } \\
\text { workers }\end{array}$ & Self-employed \\
\hline 6 & Semi-routine workers & \\
\hline 7 & Routine workers & \\
\hline
\end{tabular}

Note

(a) With more than 25 employees. 
FIGURE 1: Distribution (\%) of Fellows by parental class and indices of homogenity, by birth cohort
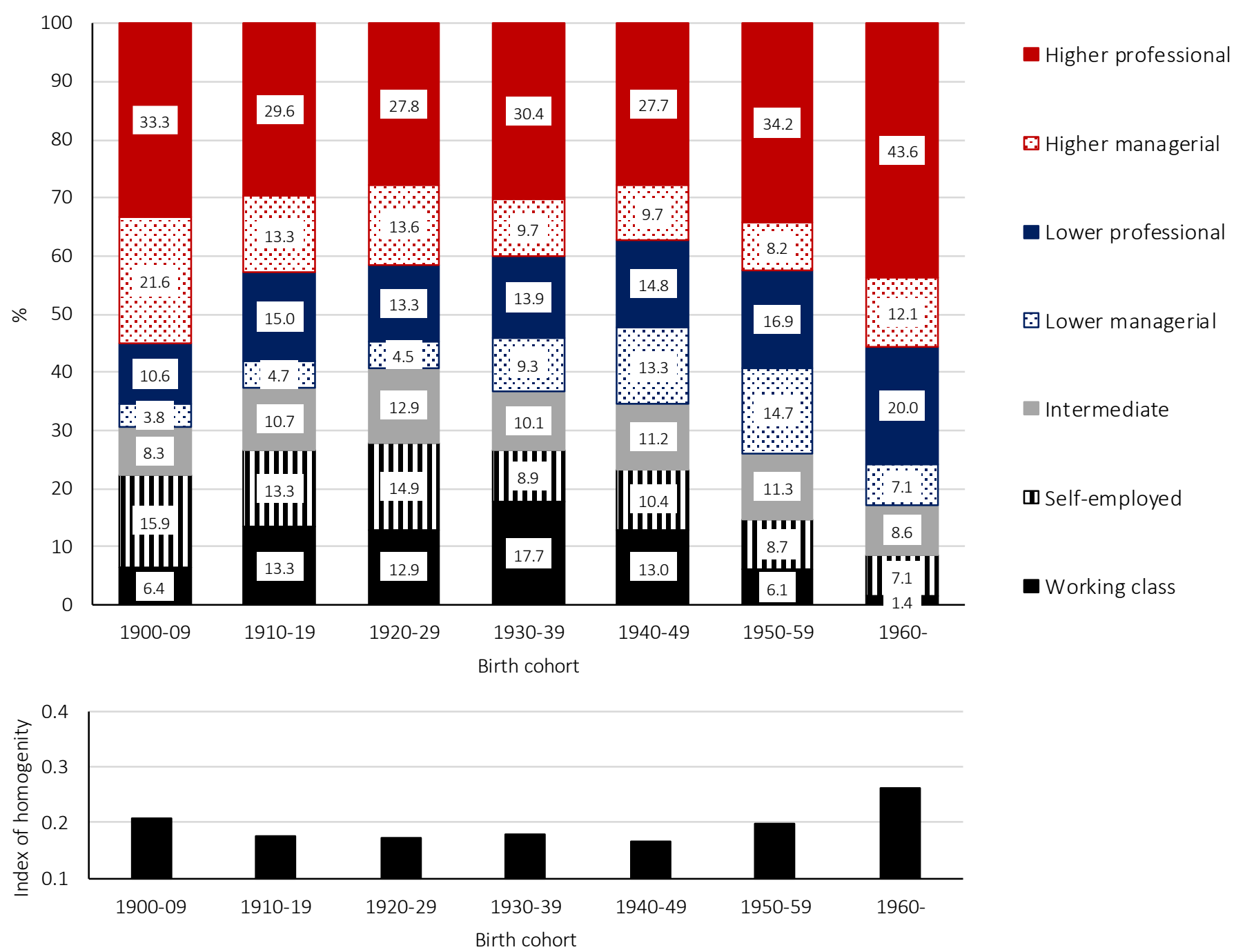
FIGURE 2: Comparison of the parental class distributions of Fellows with those of the adult population at large by birth cohort (\%); indices of dissimilarity and of homogenity

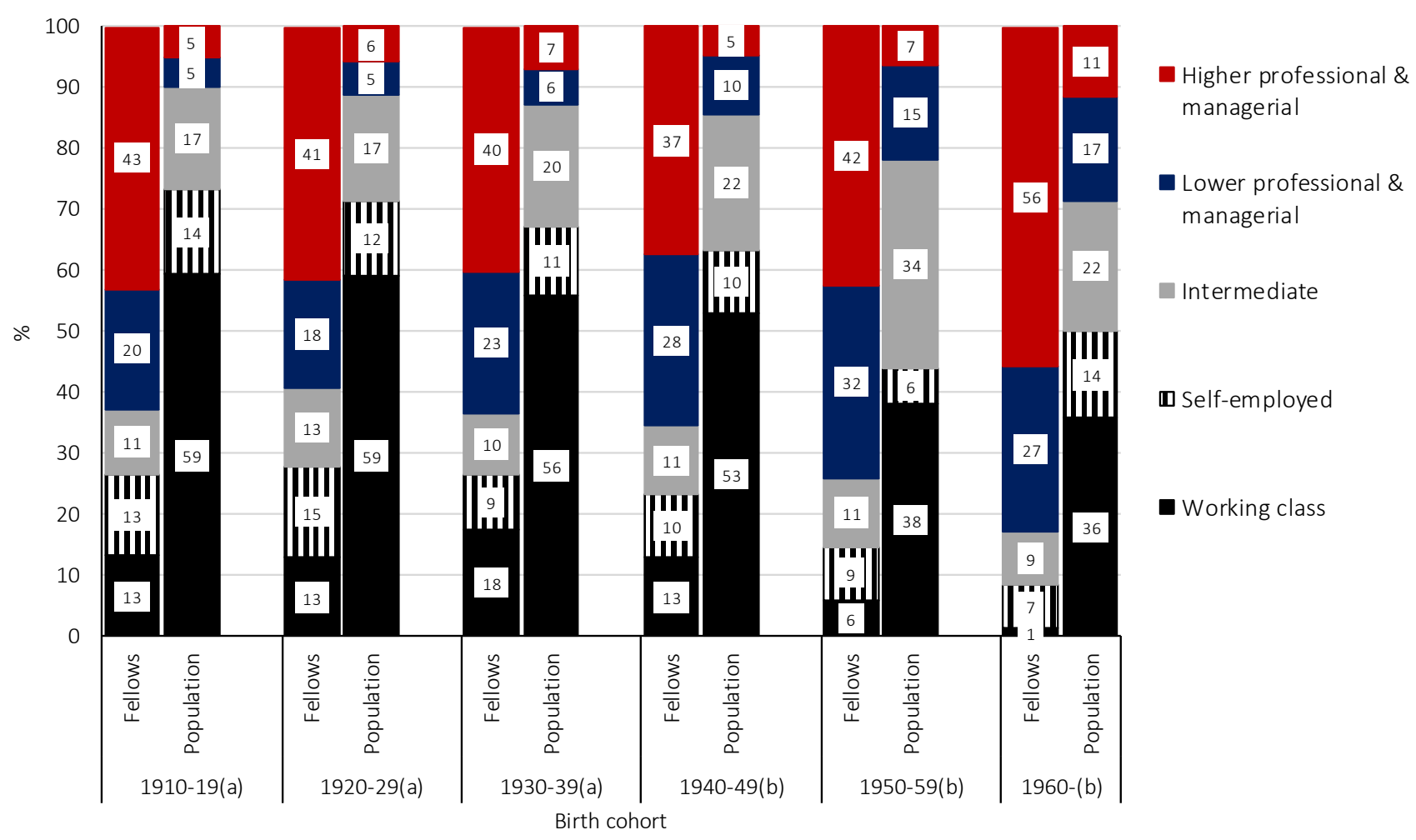

Index of dissimilarity

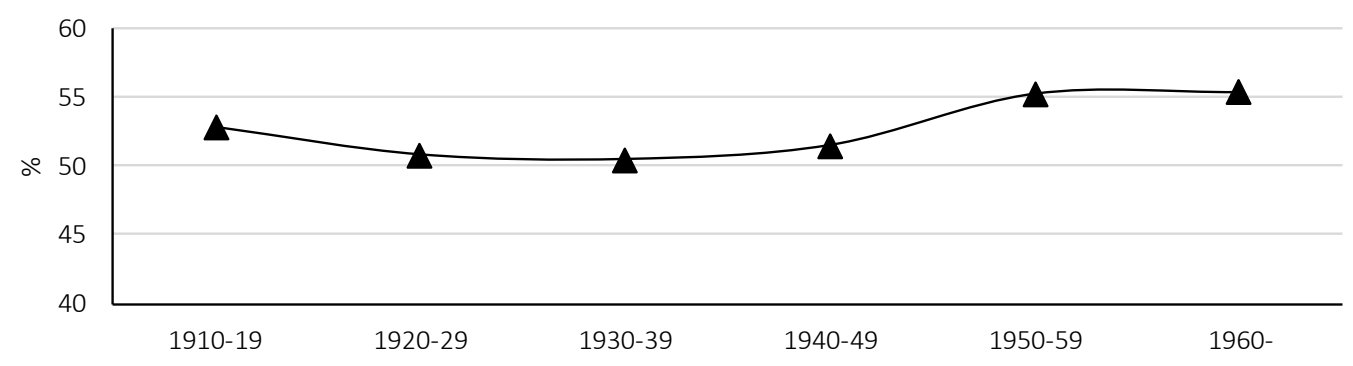

Index of homogenity

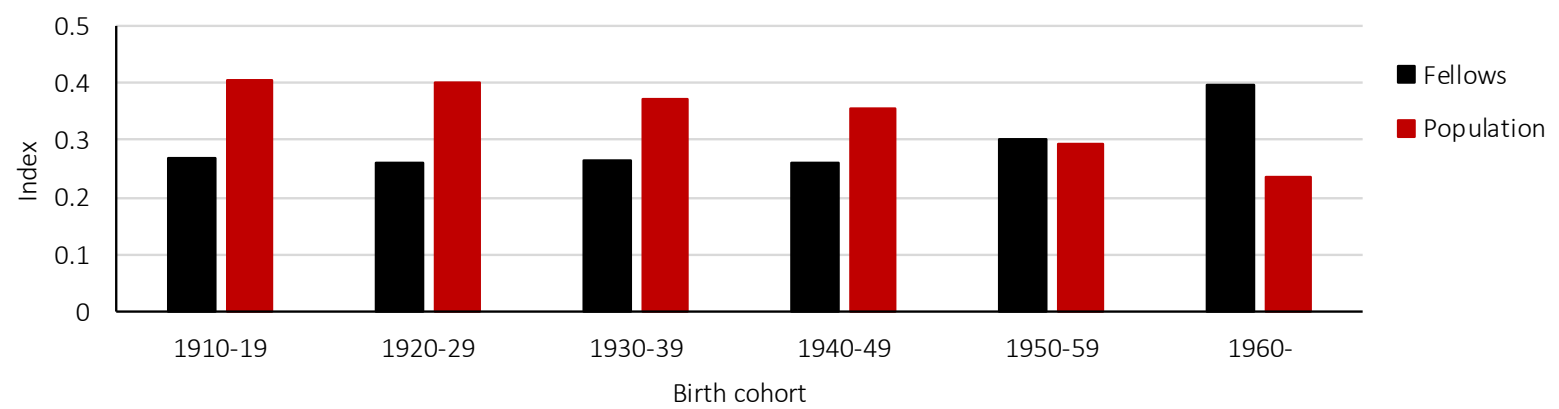

Notes

(a) Source: Oxford Social Mobility Study, 1972.

(b) Source: 1946, 1958 and 1970 British Birth Cohort studies. 
FIGURE 3: Proportion (\%) of Fellows whose parents were in STEM occupations by parental class and birth cohort, and proportion (\%) of professional parents in STEM occupations by birth cohort

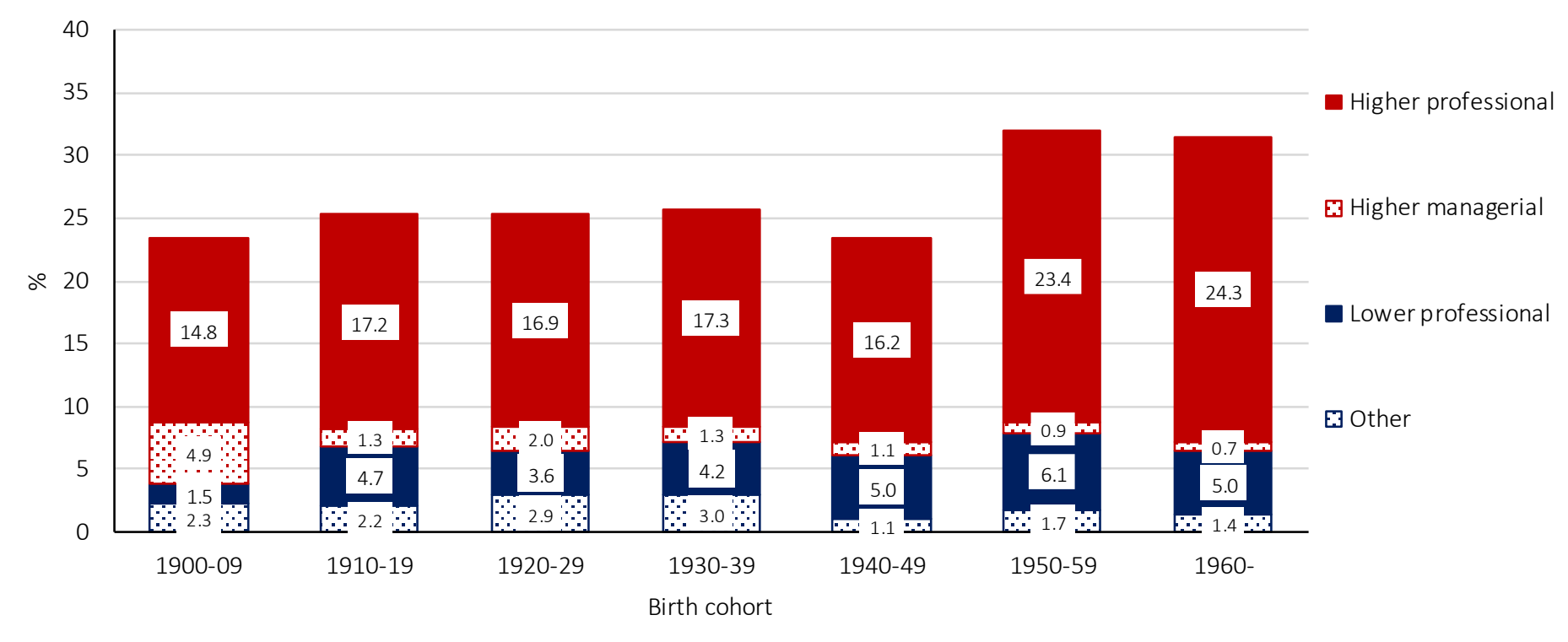

Proportion (\%) of professional parents in STEM occupations

\begin{tabular}{lccccccccc} 
& $1900-09$ & $1910-19$ & $1920-29$ & $1930-39$ & $1940-49$ & $1950-59$ & $1960-$ & All \\
\hline Higher professional & 44.3 & 58.0 & 61.2 & 56.9 & 58.4 & 68.4 & 55.7 & 57.4 \\
Lower professional & 14.3 & 31.4 & 26.8 & 30.3 & 34.2 & 35.9 & 25.0 & 29.0
\end{tabular}


TABLE 3: Distribution (\%) of Fellows by parental class and indices of homogenity, by subject area

\begin{tabular}{|c|c|c|c|c|c|c|c|c|c|c|}
\hline Subject Area $(S A)^{(a)}$ & $\begin{array}{c}\text { Higher } \\
\text { professional }\end{array}$ & $\begin{array}{c}\text { Higher } \\
\text { managerial }\end{array}$ & $\begin{array}{c}\text { Lower } \\
\text { professional }\end{array}$ & $\begin{array}{c}\text { Lower } \\
\text { managerial }\end{array}$ & Intermediate & $\begin{array}{c}\text { Self- } \\
\text { employed }\end{array}$ & $\begin{array}{c}\text { Working } \\
\text { class }\end{array}$ & Total & $\mathrm{N}$ & $\begin{array}{c}\text { Index of } \\
\text { homogenity }\end{array}$ \\
\hline 1 Mathematics, computer science & 35.9 & 10.7 & 12.6 & 8.8 & 9.4 & 12.0 & 10.7 & 100.0 & 159 & 0.20 \\
\hline 2 Astronomy, physics & 28.1 & 12.6 & 16.1 & 7.4 & 10.2 & 13.3 & 12.3 & 100.0 & 285 & 0.17 \\
\hline 3 Chemistry & 21.4 & 12.6 & 14.6 & 7.8 & 11.7 & 16.5 & 15.5 & 100.0 & 206 & 0.15 \\
\hline 4 Engineering, technology & 27.2 & 13.9 & 15.0 & 8.9 & 14.4 & 10.0 & 10.6 & 100.0 & 180 & 0.17 \\
\hline 5 Earth sciences, environmental physical sciences & 37.2 & 12.8 & 11.7 & 7.5 & 7.5 & 9.6 & 13.8 & 100.0 & 94 & 0.21 \\
\hline 6 Biochemistry, structural biology, molecular cell biology & 29.2 & 10.7 & 14.0 & 8.4 & 11.2 & 11.2 & 15.2 & 100.0 & 178 & 0.17 \\
\hline 7 Developmental biology and genetics, immunology, microbiology & 33.3 & 15.2 & 20.3 & 4.4 & 9.4 & 12.3 & 5.1 & 100.0 & 138 & 0.20 \\
\hline 8 Anatomy, physiology, neuroscience & 42.0 & 12.7 & 12.7 & 5.7 & 10.8 & 7.0 & 8.9 & 100.0 & 157 & 0.24 \\
\hline 9 Organismal biology, evolutionary and ecological science & 32.8 & 16.4 & 11.3 & 12.3 & 9.2 & 11.8 & 6.2 & 100.0 & 195 & 0.19 \\
\hline 10 Health and human sciences & 38.4 & 8.1 & 16.2 & 10.1 & 11.1 & 10.1 & 6.1 & 100.0 & 99 & 0.22 \\
\hline Total & 31.4 & 12.8 & 14.5 & 8.2 & 10.6 & 11.8 & 10.8 & 100.0 & 1691 & 0.18 \\
\hline
\end{tabular}

Note

(a) For full details, see Appendix 2 
TABLE 4: Effects of parental class and birth cohort on probabilities of Fellows being found in four research fields; average marginal effects (\%) from a multinomial logit model

\begin{tabular}{lcccc}
\hline & $\begin{array}{c}\text { Maths, Physical } \\
\text { Sciences } \\
\text { SAs 1, 2, 4, 5 }\end{array}$ & $\begin{array}{c}\text { Chemistry } \\
\text { SA 3 }\end{array}$ & $\begin{array}{c}\text { Other Biological } \\
\text { Biochemistry, } \\
\text { etc. SA 6 }\end{array}$ & $\begin{array}{c}\text { Sciences } \\
\text { SAs 7, 8, 9, 10 }\end{array}$ \\
\hline Cohort & & & & -2.5 \\
1900-29 & 3.9 & 2.3 & -3.7 \\
1930-49 (ref.) & 0.0 & 0.0 & 0.0 & 0.0 \\
1950- & -0.7 & -0.9 & 4.0 & -2.3 \\
& & & & \\
Parental class & 0.0 & 0.0 & 0.0 & 0.0 \\
Higher professional (ref.) & -1.0 & 4.0 & -0.5 & -2.5 \\
Higher managerial & 0.4 & 4.6 & 0.2 & -5.2 \\
Lower professional & 0.7 & 4.4 & 0.3 & -5.4 \\
Lower managerial & 0.5 & 5.5 & 1.5 & -7.4 \\
Intermediate & -0.2 & 8.2 & 1.0 & -9.1 \\
Self-employed & 6.0 & 9.3 & 4.1 & -20.4 \\
Working class & & &
\end{tabular}


FIGURE 4: Distribution of Fellows (\%) by type of secondary school attended, by birth cohort

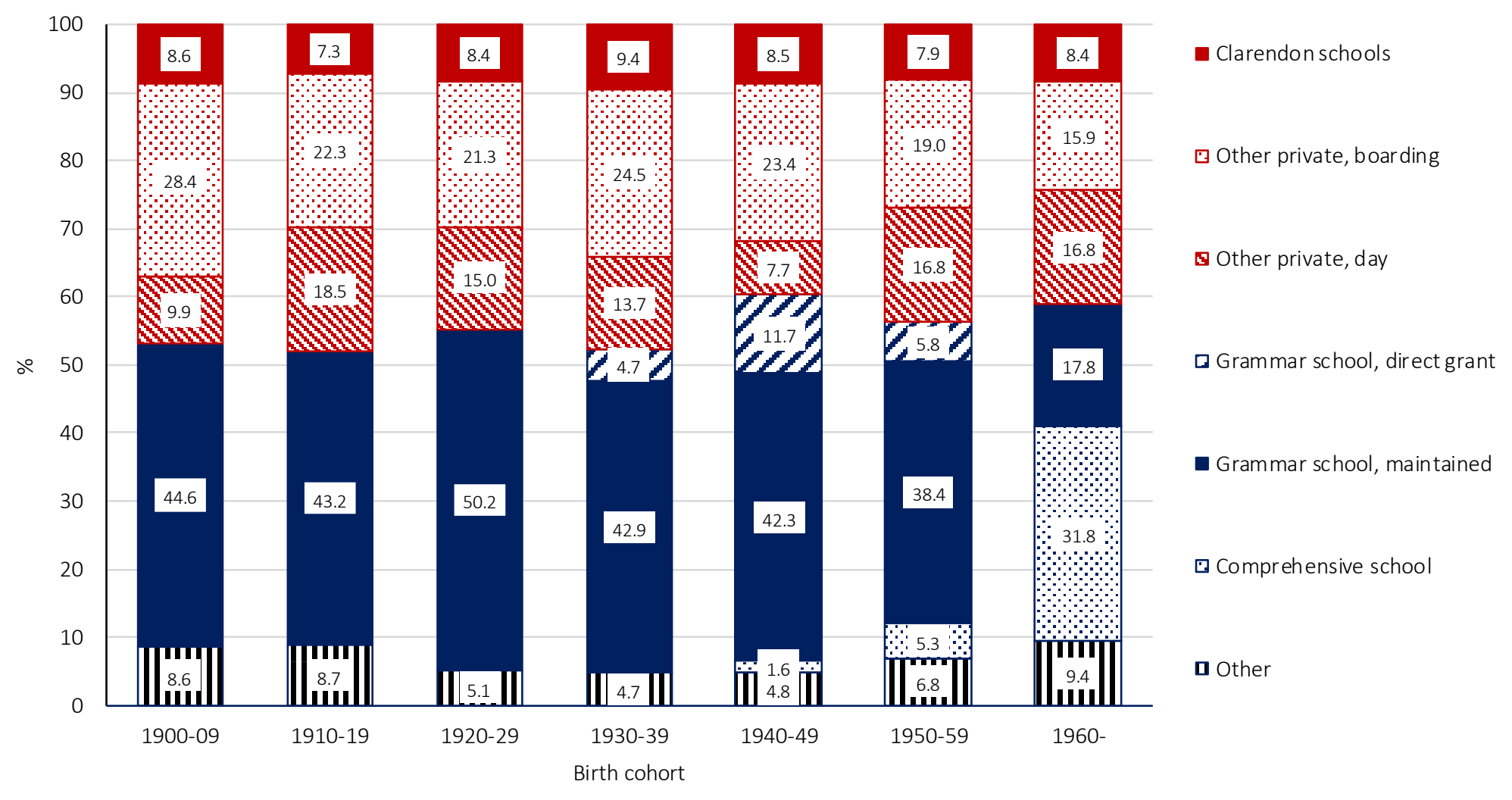


TABLE 5: Distribution of Fellows attending Clarendon schools by school

\begin{tabular}{lr}
\hline & $\%$ \\
\hline St Paul's School & 19.3 \\
Winchester & 17.8 \\
Westminster & 16.3 \\
Eton & 11.9 \\
Rugby & 11.1 \\
Merchant Taylors' & 8.1 \\
Charterhouse & 6.7 \\
Shrewsbury & 5.8 \\
Harrow & 3.0 \\
& \\
Total & 100.0 \\
$\mathrm{~N}$ & 122 \\
\hline
\end{tabular}


FIGURE 5: Percentage of Clarendon school alumni among Fellows and among those included in Who's Who, in different elites, by birth cohort

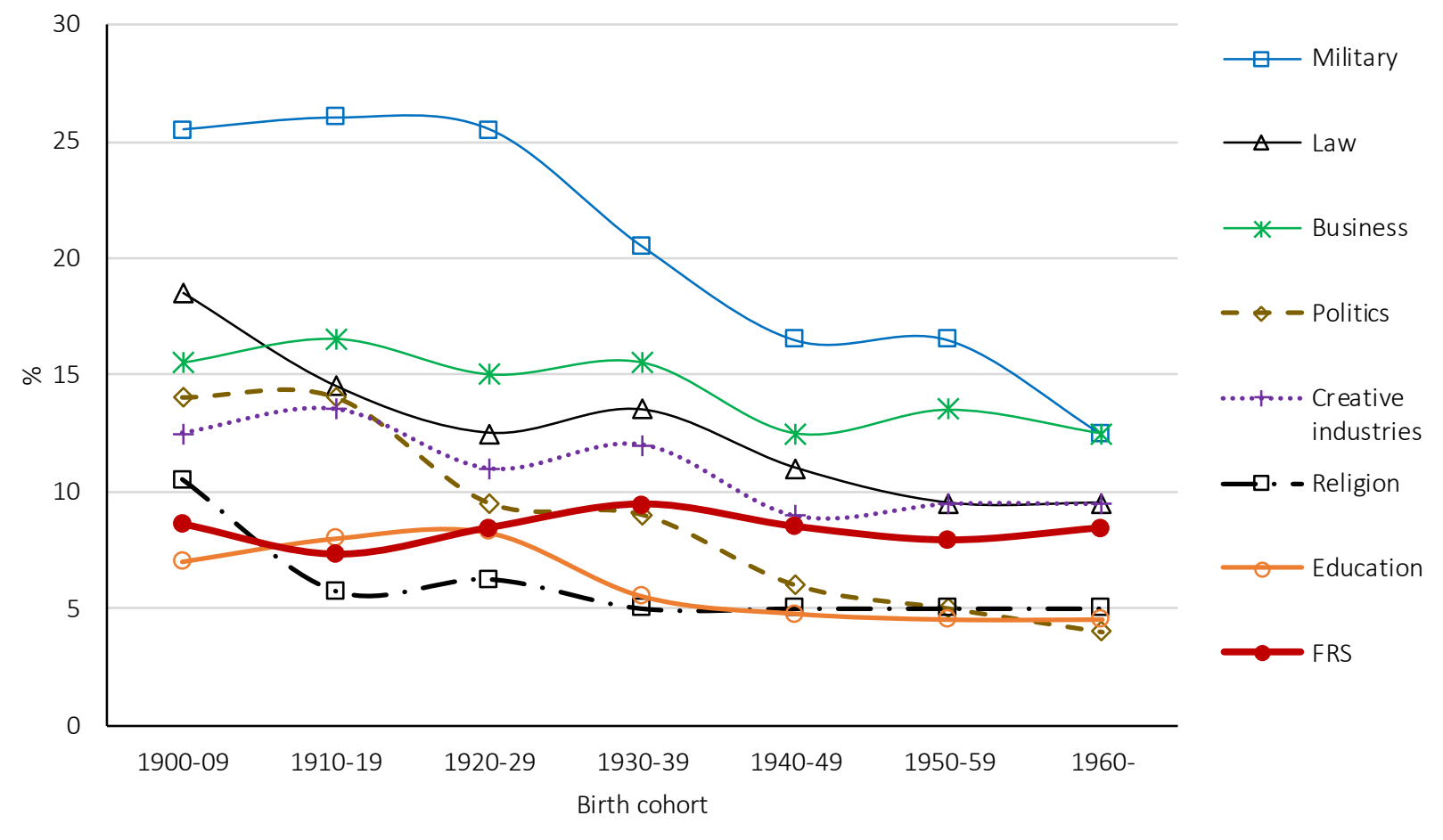

Source: Reeves et al. (2017), Appendix Part F 
TABLE 6: Distribution (\%) of Fellows by type of secondary school attended, by parental class

\begin{tabular}{|c|c|c|c|c|c|c|c|c|c|}
\hline \multirow[b]{2}{*}{ Parental class } & \multicolumn{3}{|c|}{ Private school } & \multicolumn{2}{|c|}{ Grammar school } & \multirow{2}{*}{$\begin{array}{c}\text { Comprehensive } \\
\text { school }\end{array}$} & \multirow[b]{2}{*}{ Other } & \multirow[b]{2}{*}{ Total } & \multirow[b]{2}{*}{$\mathrm{N}$} \\
\hline & Clarendon & $\begin{array}{c}\text { other, } \\
\text { boarding }\end{array}$ & $\begin{array}{c}\text { other, } \\
\text { day }\end{array}$ & $\begin{array}{l}\text { direct } \\
\text { grant }\end{array}$ & maintained & & & & \\
\hline Higher professional & 16.5 & 35.8 & 19.0 & 2.9 & 20.4 & 2.5 & 2.9 & 100.0 & 442 \\
\hline STEM & 16.4 & 37.6 & 18.8 & 2.8 & 18.4 & 2.8 & 3.2 & 100.0 & 250 \\
\hline Non-STEM & 16.8 & 33.5 & 19.4 & 3.1 & 22.5 & 2.1 & 2.6 & 100.0 & 191 \\
\hline Higher managerial & 14.5 & 42.2 & 11.5 & 4.2 & 21.1 & 1.8 & 4.8 & 100.0 & 166 \\
\hline Lower professional & 2.8 & 19.1 & 14.0 & 3.3 & 50.7 & 4.7 & 5.6 & 100.0 & 215 \\
\hline Lower managerial & 6.2 & 16.2 & 15.4 & 3.9 & 48.5 & 5.4 & 4.6 & 100.0 & 130 \\
\hline Intermediate & 1.8 & 6.5 & 7.1 & 5.3 & 71.0 & 4.1 & 4.1 & 100.0 & 169 \\
\hline Self-employed & 4.7 & 14.5 & 11.6 & 2.3 & 51.7 & 4.1 & 11.1 & 100.0 & 172 \\
\hline Working class & 0.0 & 2.4 & 8.5 & 3.1 & 65.2 & 1.8 & 18.9 & 100.0 & 164 \\
\hline Total & 8.4 & 22.7 & 13.7 & 3.4 & 42.0 & 3.3 & 6.6 & 100.0 & 1457 \\
\hline
\end{tabular}


TABLE 7: Effects of parental class and birth cohort on probabilities of Fellows having attended private school rather than state school and different types of private school; average marginal effects (\%) from binomial and multinomial logit models

\begin{tabular}{lcccc}
\hline & $\begin{array}{c}\text { Private } \\
\text { school }\end{array}$ & \multicolumn{3}{c}{ Type of private school } \\
\cline { 3 - 5 } & & Clarendon & $\begin{array}{c}\text { other } \\
\text { boarding }\end{array}$ & $\begin{array}{c}\text { other } \\
\text { day }\end{array}$ \\
\hline Cohort & 1.1 & -1.2 & -1.4 & 3.7 \\
1900-29 & 0.0 & 0.0 & 0.0 & 0.0 \\
1930-49 (ref.) & -4.7 & -1.6 & -8.7 & 5.6 \\
1950- & & & & \\
& & & & 0.0 \\
Parental class & 0.0 & 0.0 & 0.0 & 0.0 \\
Higher professional (ref.) & -5.0 & -1.0 & 3.2 & -7.2 \\
Higher managerial & -29.3 & -13.3 & -11.5 & -4.5 \\
Lower professional & -27.5 & -7.3 & -16.2 & -4.0 \\
Lower managerial & -46.6 & -13.0 & -26.2 & -7.5 \\
Other ${ }^{(a)}$ & & & & \\
\hline
\end{tabular}

Note

(a) The table of parental class by type of secondary school by birth cohort has empty cells. For this reason, the last three categories of our parental class variable are collapsed. 
TABLE 8: Distributions (\%) of Fellows by type of secondary school attended, separately by subject area

\begin{tabular}{|c|c|c|c|c|c|c|c|c|c|}
\hline \multirow[b]{2}{*}{ Subject Area $(S A)^{(a)}$} & \multicolumn{3}{|c|}{ Private school } & \multicolumn{2}{|c|}{ Grammar school } & \multirow{2}{*}{$\begin{array}{c}\text { Comprehensive } \\
\text { school }\end{array}$} & \multirow[b]{2}{*}{ Other } & \multirow[b]{2}{*}{ Total } & \multirow[b]{2}{*}{ N } \\
\hline & Clarendon & $\begin{array}{l}\text { other } \\
\text { boarding }\end{array}$ & $\begin{array}{l}\text { other } \\
\text { day }\end{array}$ & $\begin{array}{l}\text { direct } \\
\text { grant }\end{array}$ & maintained & & & & \\
\hline 1 Mathematics, computer science & 7.5 & 21.8 & 12.8 & 3.8 & 45.1 & 3.8 & 5.3 & 100.0 & 133 \\
\hline 2 Astronomy, physics & 7.6 & 18.5 & 13.0 & 2.5 & 50.0 & 2.5 & 5.9 & 100.0 & 238 \\
\hline 3 Chemistry & 4.2 & 15.7 & 15.7 & 2.1 & 50.3 & 4.2 & 7.9 & 100.0 & 191 \\
\hline 4 Engineering, technology & 6.7 & 22.4 & 15.8 & 2.4 & 41.2 & 2.4 & 9.1 & 100.0 & 165 \\
\hline 5 Earth sciences, environmental physical sciences & 3.6 & 25.3 & 16.9 & 2.4 & 43.4 & 2.4 & 6.0 & 100.0 & 83 \\
\hline 6 Biochemistry, structural biology, molecular cell biology & 8.7 & 20.1 & 15.4 & 4.7 & 37.6 & 6.0 & 7.4 & 100.0 & 149 \\
\hline 7 Developmental biology and genetics, immunology, microbiology & 11.4 & 22.9 & 11.4 & 5.7 & 41.0 & 1.9 & 5.7 & 100.0 & 105 \\
\hline 8 Anatomy, physiology, neuroscience & 12.5 & 28.7 & 11.0 & 5.9 & 30.9 & 4.4 & 6.6 & 100.0 & 136 \\
\hline 9 Organismal biology, evolutionary and ecological science & 10.9 & 28.7 & 11.5 & 3.5 & 36.2 & 2.9 & 6.3 & 100.0 & 174 \\
\hline 10 Health and human sciences & 13.1 & 31.0 & 13.1 & 2.4 & 35.7 & 1.2 & 3.6 & 100.0 & 84 \\
\hline Total & 8.4 & 22.7 & 13.7 & 3.4 & 42.0 & 3.3 & 6.6 & 100.0 & 1457 \\
\hline
\end{tabular}


TABLE 9: Effects of parental class and attending private rather than state schools on probabilities of Fellows being found in four research fields with cohort as a control variable; average marginal effects (\%) from multinomial logit models

\begin{tabular}{|c|c|c|c|c|c|c|c|c|}
\hline & \multicolumn{2}{|c|}{$\begin{array}{l}\text { Maths, Physical } \\
\text { Sciences } \\
\text { SAs 1, 2, 4, } 5\end{array}$} & \multicolumn{2}{|c|}{ Chemistry, SA 3} & \multicolumn{2}{|c|}{$\begin{array}{l}\text { Biochemistry, etc. } \\
\text { SA } 6\end{array}$} & \multicolumn{2}{|c|}{$\begin{array}{l}\text { Other Biological } \\
\text { Sciences } \\
\text { SAs 7, 8, 9, } 10\end{array}$} \\
\hline & Model 1 & Model 2 & Model 1 & Model 2 & Model 1 & Model 2 & Model 1 & Model 2 \\
\hline \multicolumn{9}{|l|}{ Parental class } \\
\hline Higher professional (ref.) & 0.0 & 0.0 & 0.0 & 0.0 & 0.0 & 0.0 & 0.0 & 0.0 \\
\hline Higher managerial & -3.7 & -3.9 & 5.6 & 5.5 & 1.8 & 1.7 & -3.5 & -3.3 \\
\hline Lower professional & 3.8 & 2.7 & 3.6 & 2.4 & 1.6 & 0.9 & -8.2 & -6.6 \\
\hline Lower managerial & 0.4 & -0.6 & 4.2 & 3.1 & 1.8 & 1.1 & -5.8 & -4.3 \\
\hline Intermediate & 0.9 & -0.8 & 5.5 & 3.6 & 4.4 & 3.3 & -9.7 & -7.2 \\
\hline Self-employed & 0.5 & -0.8 & 8.9 & 7.5 & 2.3 & 1.5 & -10.9 & -9.0 \\
\hline Working class & 9.3 & 7.3 & 9.2 & 7.2 & 6.4 & 5.2 & -24.7 & -21.9 \\
\hline \multicolumn{9}{|l|}{ Type of secondary school } \\
\hline State (ref.) & & 0.0 & & 0.0 & & 0.0 & & 0.0 \\
\hline Private & & -3.1 & & -3.4 & & 2.0 & & 4.7 \\
\hline \multicolumn{9}{|l|}{ Cohort } \\
\hline $1900-29$ & 4.9 & 4.9 & 2.4 & 2.5 & -3.9 & -3.9 & -3.5 & -3.5 \\
\hline 1930-49 (ref.) & 0.0 & 0.0 & 0.0 & 0.0 & 0.0 & 0.0 & 0.0 & 0.0 \\
\hline $1950-$ & -1.4 & -1.6 & 0.4 & 0.2 & 2.1 & 2.2 & -1.0 & -0.8 \\
\hline
\end{tabular}


APPENDICES 
APPENDIX 1: Number of Fellows elected in each year since $1945^{(a)}$

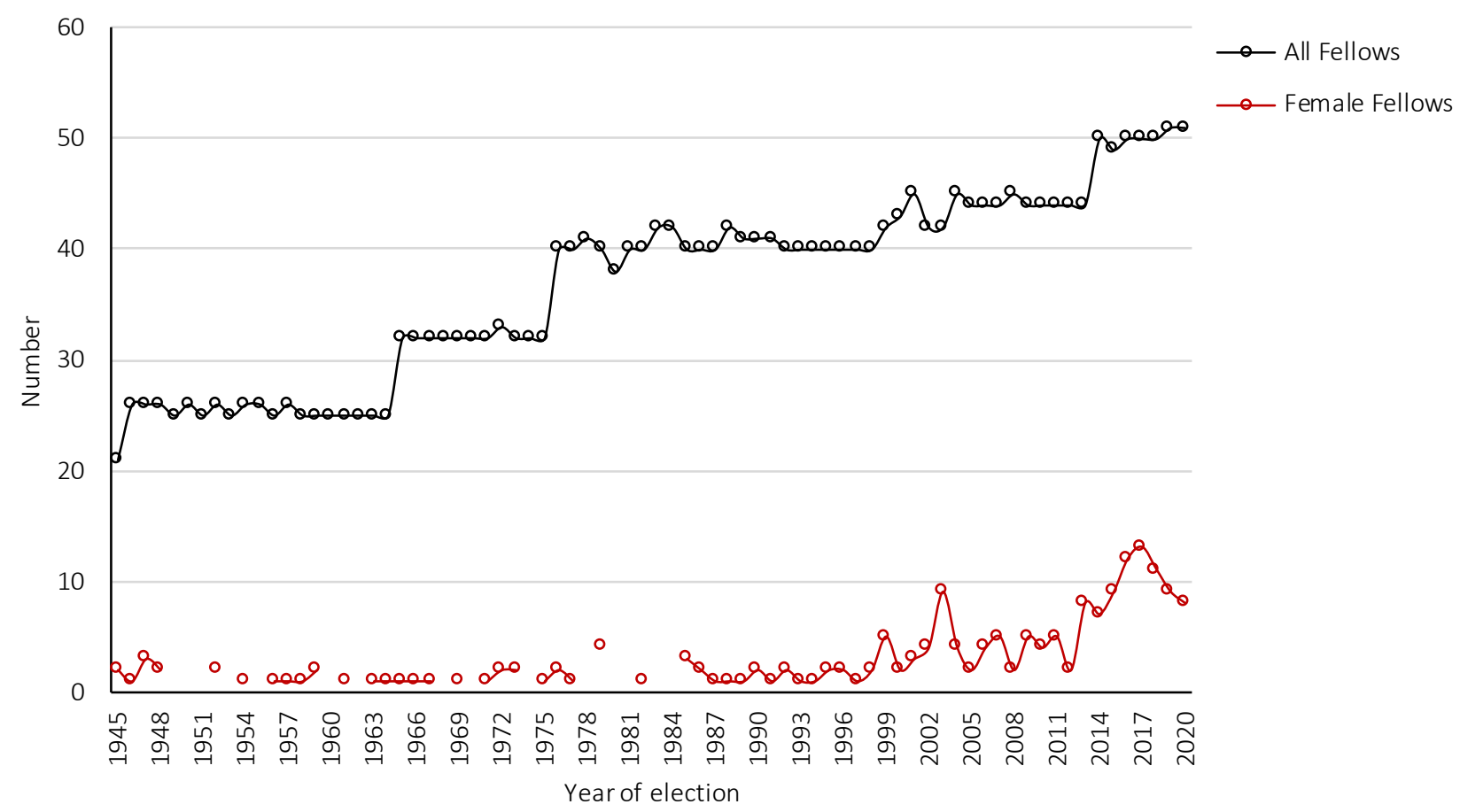

Note

(a) Foreign, Honorary and Royal Fellows are excluded.

Source: https://royalsociety.org/fellows/ 
APPENDIX 2.1: Differences between living and deceased Fellows in estimated probabilities of coming from different class origins, average marginal effects (\%) from a multinomial logit model

\begin{tabular}{lccccc}
\hline & \multicolumn{5}{c}{ Parental class } \\
\cline { 2 - 6 } & $\begin{array}{c}\text { Higher } \\
\text { professional }\end{array}$ & $\begin{array}{c}\text { Higher } \\
\text { managerial }\end{array}$ & $\begin{array}{c}\text { Lower } \\
\text { professional }\end{array}$ & $\begin{array}{c}\text { Lower } \\
\text { managerial }\end{array}$ & Other \\
\hline $\begin{array}{l}\text { Fellows living } \\
\text { Yes (ref.) }\end{array}$ & 0.0 & 0.0 & 0.0 & 0.0 & 0.0 \\
No & 0.9 & -0.3 & -1.4 & -1.3 & 1.0 \\
Cohort & & & & & \\
$1900-29$ & 0.1 & 6.6 & 0.3 & -6.0 & -1.0 \\
$1930-49$ (ref.) & 0.0 & 0.0 & 0.0 & 0.0 & 0.0 \\
$1950-$ & 10.6 & 0.3 & 3.1 & -0.1 & -12.9 \\
\hline
\end{tabular}


APPENDIX 2.2: Differences between living and deceased Fellows coming from different class of origins in estimated probabilities of attending private rather than state secondary school, average marginal effects (\%) from binomial logit models

\begin{tabular}{lrr}
\hline & Model 1 & Model 2 \\
\hline Fellows living & & \\
Yes (ref.) & 0.0 & 0.0 \\
No & -2.1 & -2.1 \\
& & \\
Parental class & & \\
Higher professional (ref.) & 0.0 & 0.0 \\
Higher managerial & -3.7 & -4.5 \\
Lower professional & -29.2 & -35.7 \\
Lower managerial & -27.1 & -33.9 \\
Other & -46.5 & -52.6 \\
Parental class X Fellows living & & \\
Higher professional (ref.) & & 0.0 \\
Higher managerial & & -1.6 \\
Lower professional & & 3.7 \\
Lower managerial & & 3.3 \\
Other & & 2.6 \\
Cohort & & \\
1900-29 & & \\
1930-49 (ref.) & & \\
1950- & 1.0 & 0.0 \\
\hline & 0.0 & -5.0 \\
\hline
\end{tabular}


APPENDIX 3: Royal Society Subject Areas

Pure and applied mathematics, computer science: applied

1 mathematics, pure mathematics, statistics and operational research, computer systems, Al, machine learning, databases, programming languages, numerical computing, computational paradigms Astronomy, physics, theoretical physics, applied physics

3 Chemistry, applied chemistry, theoretical chemistry

Engineering, technology, instrumentation, material science, experimental fluid dynamics

Earth sciences, environmental physical sciences: archeology, mineralogy, physical geography, meteorology, atmospheric chemistry, climate science, hydrology, oceanography, limnology, geology, geodesy, geochemistry, geophysics, seismology

Biochemistry, structural biology, molecular cell biology : biochemistry and molecular biology, biophysics and structural biology, molecular immunology, molecular microbiology, cell biology

Developmental biology and genetics, immunology, microbiology:

7 developmental biology, general microbiology, immunology, cellular pathalogy, genetics (excl. population genetics), cytogenetics, epidemiology (non-clinical)

Anatomy, physiology, neurosciences: animal and human physiology, anatomy physiology, medicine (non-clinical), pharmacology (non-

8 clinical), physiology (non-clinical), endocrinology and reproduction (nonclinical), experimental psychology, behavioural neuroscience, development and control of behaviour, celluar neuroscience

Organismal biology, evolutionary and ecological science : animal biology, zoology, botany, ethology, evolution, ecology, taxonomy, popultation genetics, agriculture, environmental biology, biological modelling, biological statistics, soil science, entomology, paleozoology, parasitology

Health and human sciences: molecular medicine, medical microbiology, nutrition, medical statistics and demography, medical instrumentation 
APPENDIX 4: Estimated probabilities (\%) of Fellows being found in four research fields by parental class and birth cohort $^{(\text {a) }}$

Maths, Physical Sciences; SAs 1, 2, 4, 5

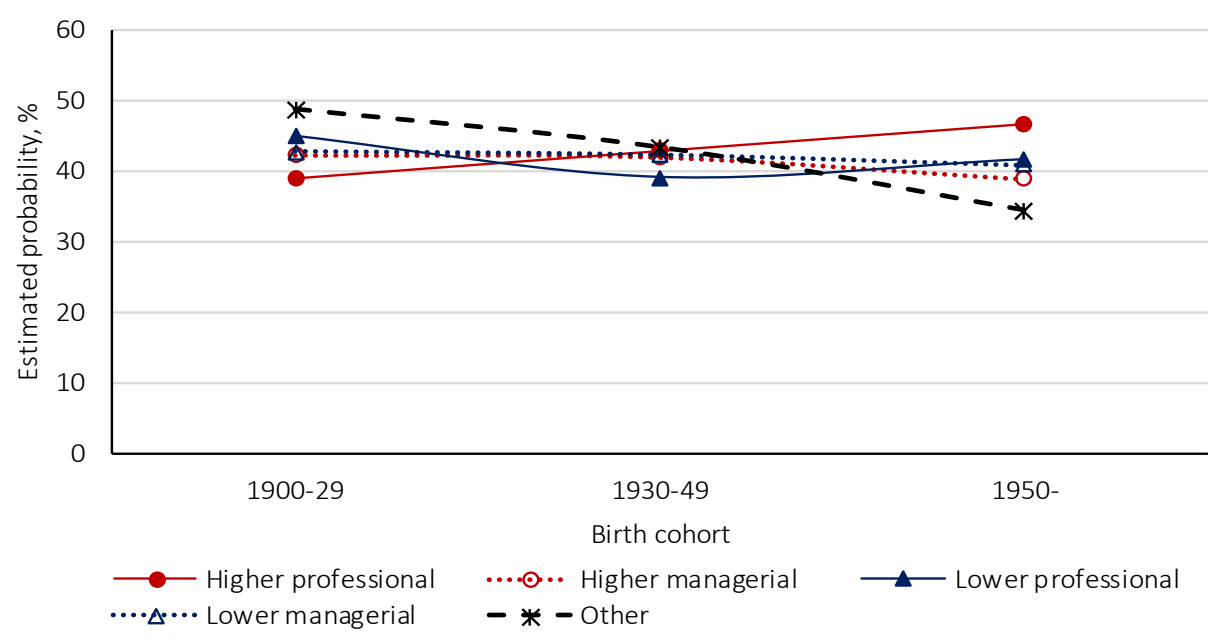

Biochemistry, etc.; SA 6

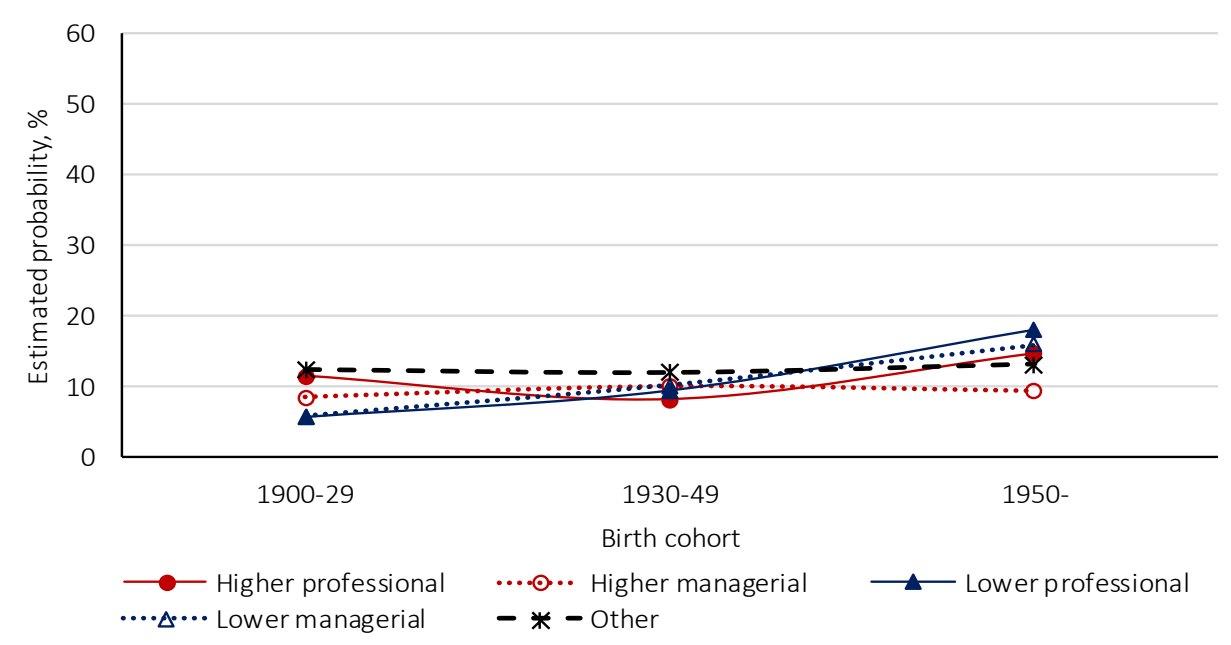

Chemistry; SA 3

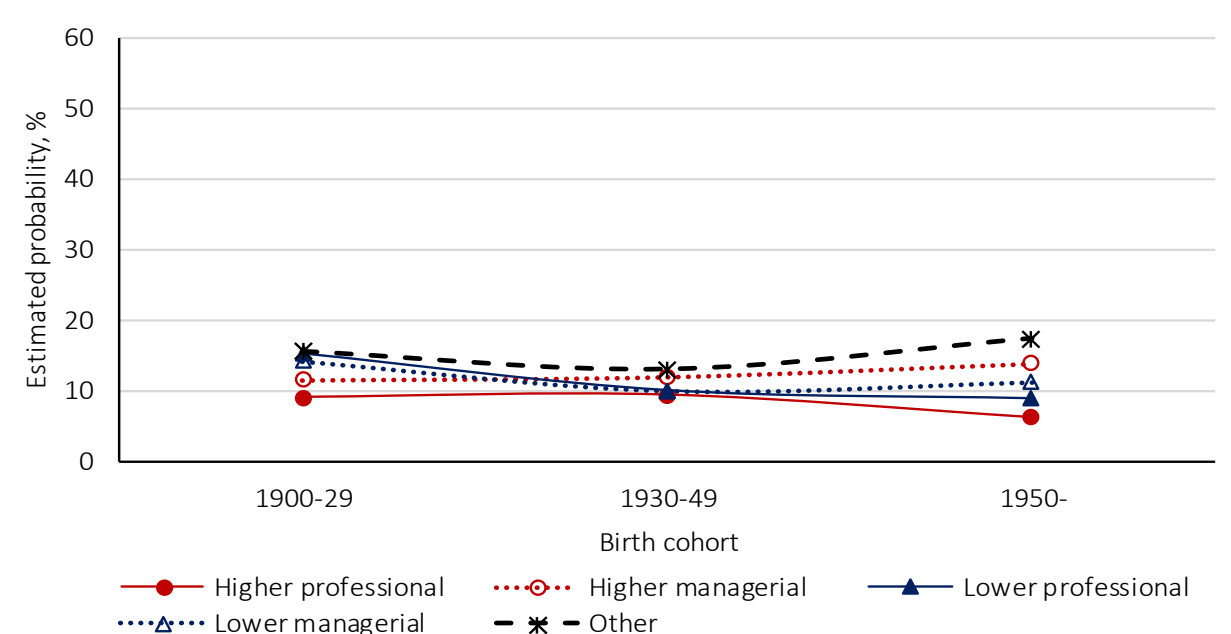

Other Biological Sciences; SAs 7, 8, 9, 10

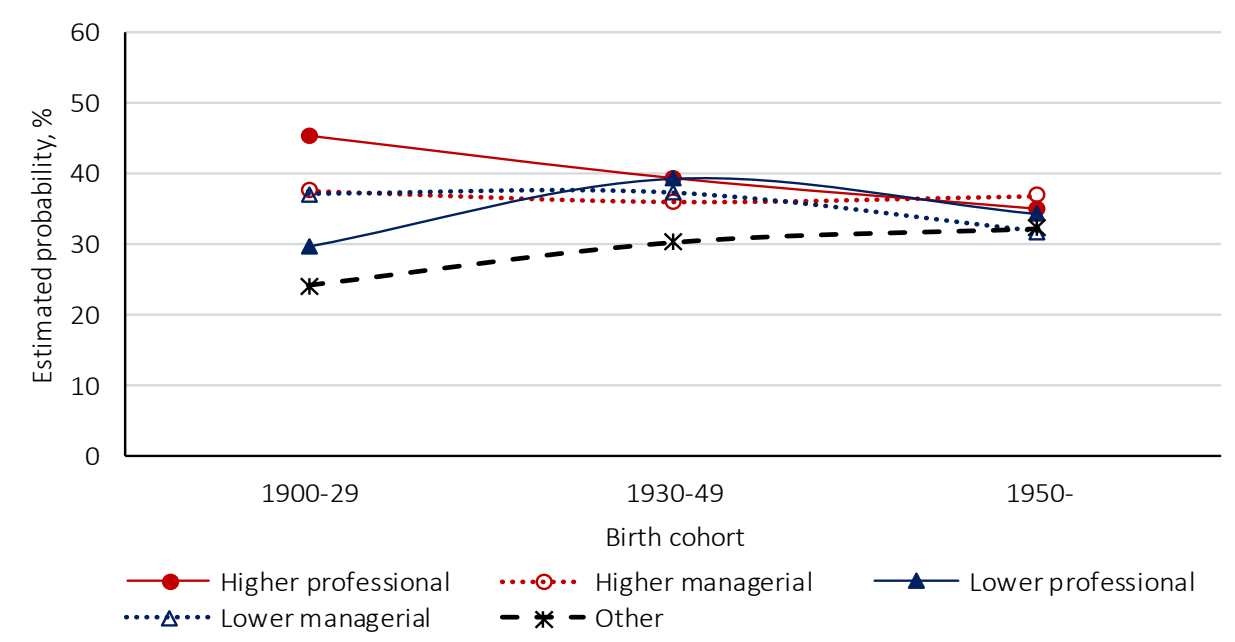

Note

(a) Based on a multinomial logit model that includes parental class, birth cohort and interactions between these two variables. 
APPENDIX 5: Estimated probabilities (\%) of Fellows having attended different types of secondary school, by parental class and birth cohort ${ }^{\text {(a) }}$

Clarendon

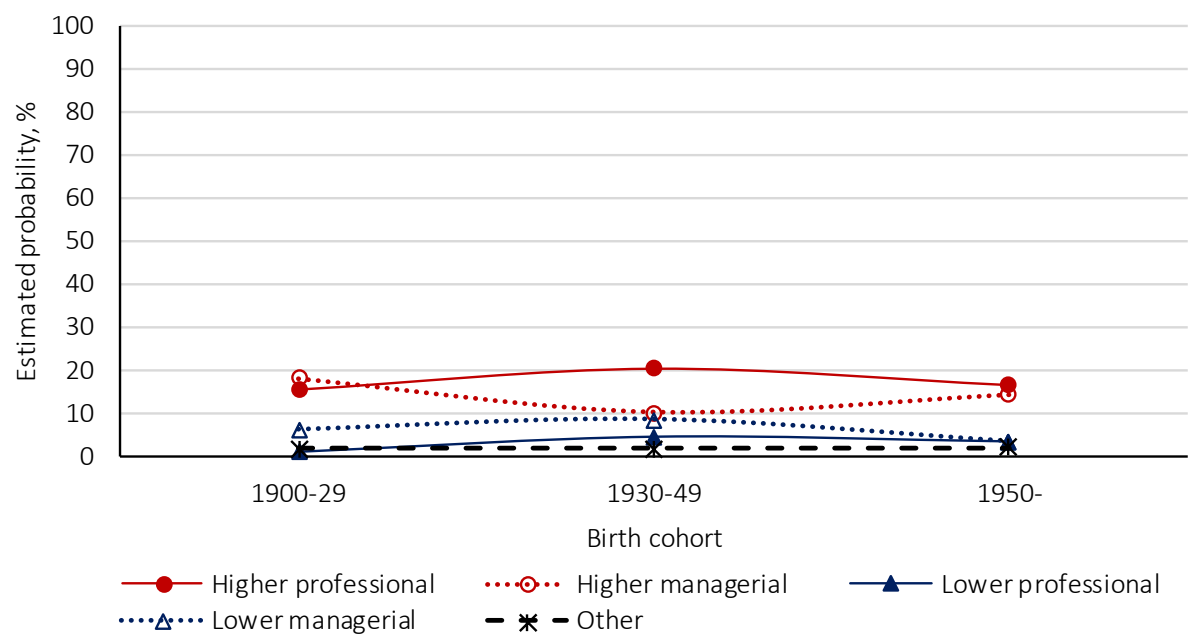

Private other, day

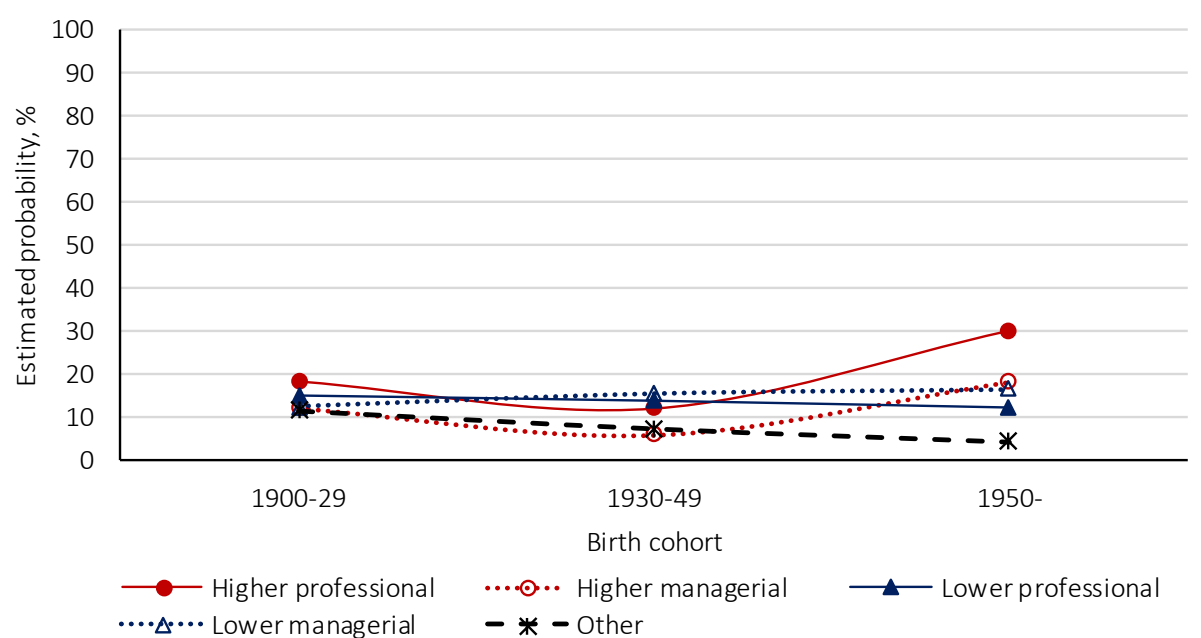

Private other, boarding

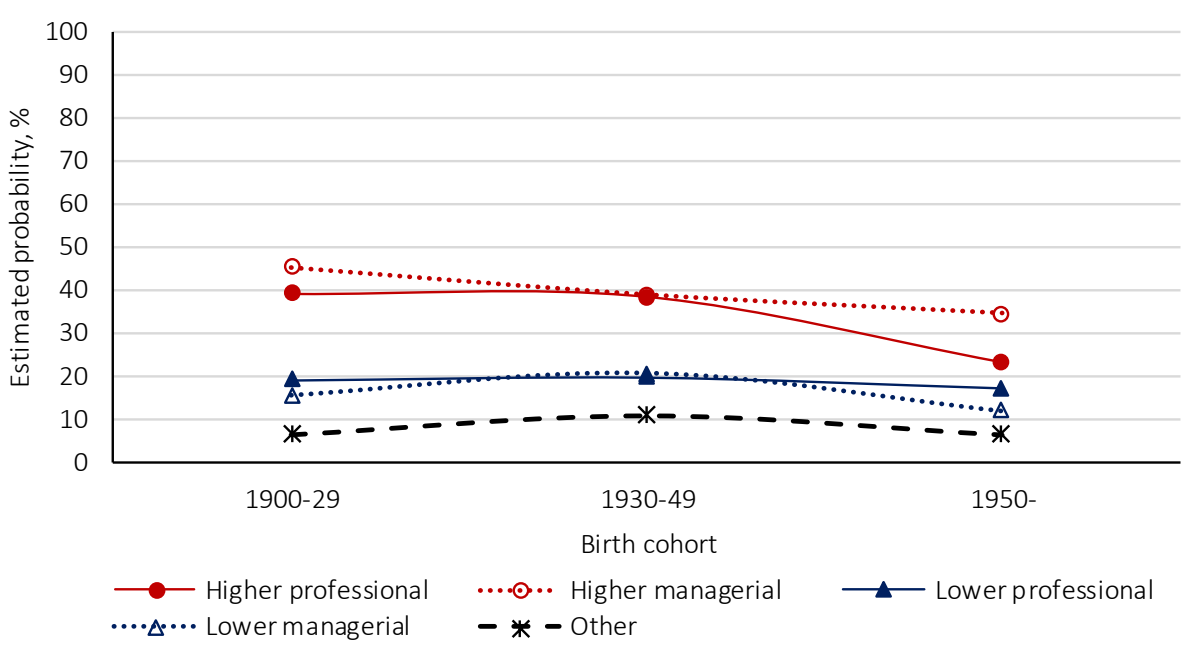

Grammar, comprehensive, other

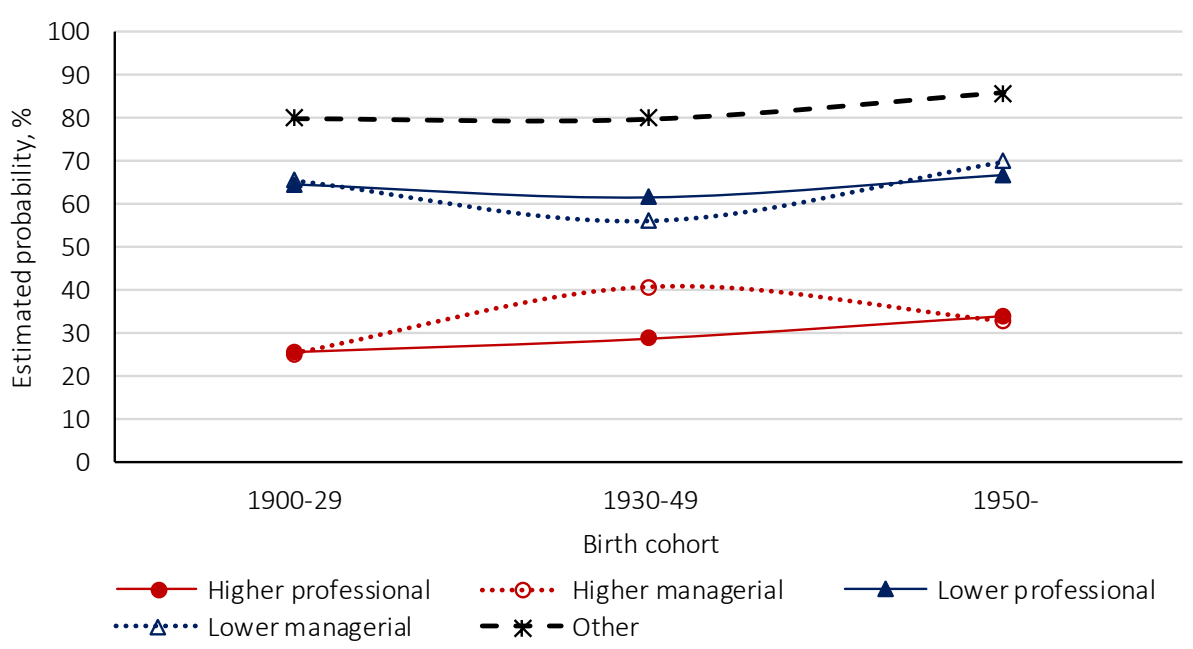

Note

(a) Based on a multinomial logit model that includes parental class, birth cohort and interactions between these two variables. 
APPENDIX 6: Estimated probabilities (\%) of Fellows being found in four research fields, by parental class and type of secondary school ${ }^{(a)(b)}$

Maths, Physical Sciences; SAs 1, 2, 4, 5

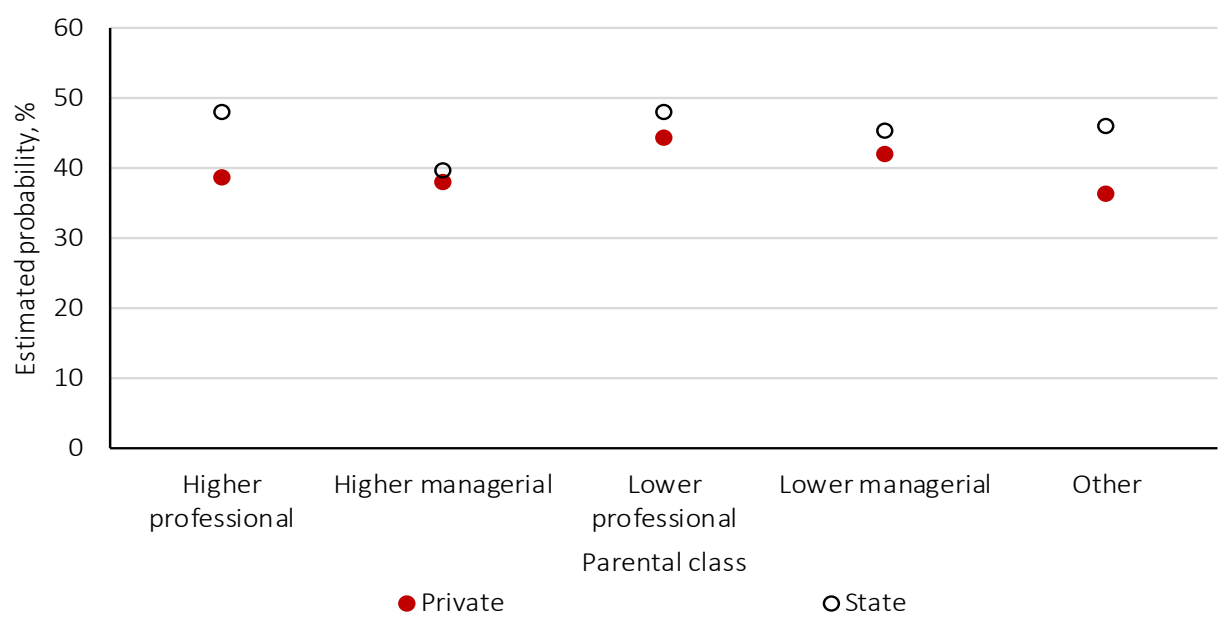

Biochemistry, etc.; SA 6

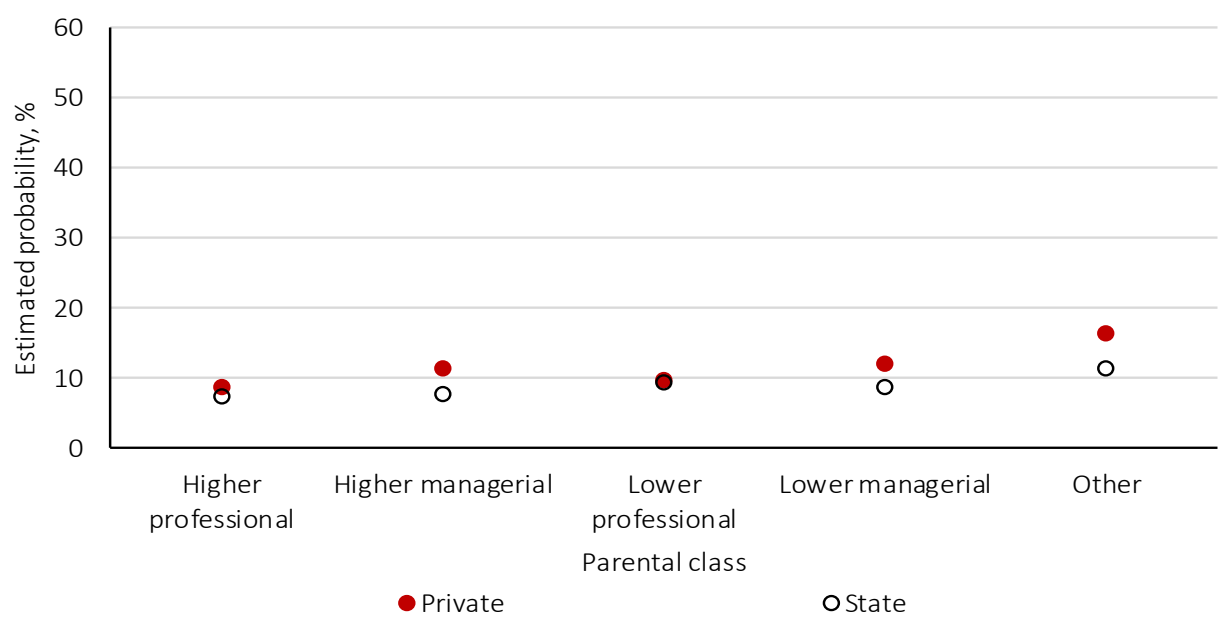

Chemistry; SA 3

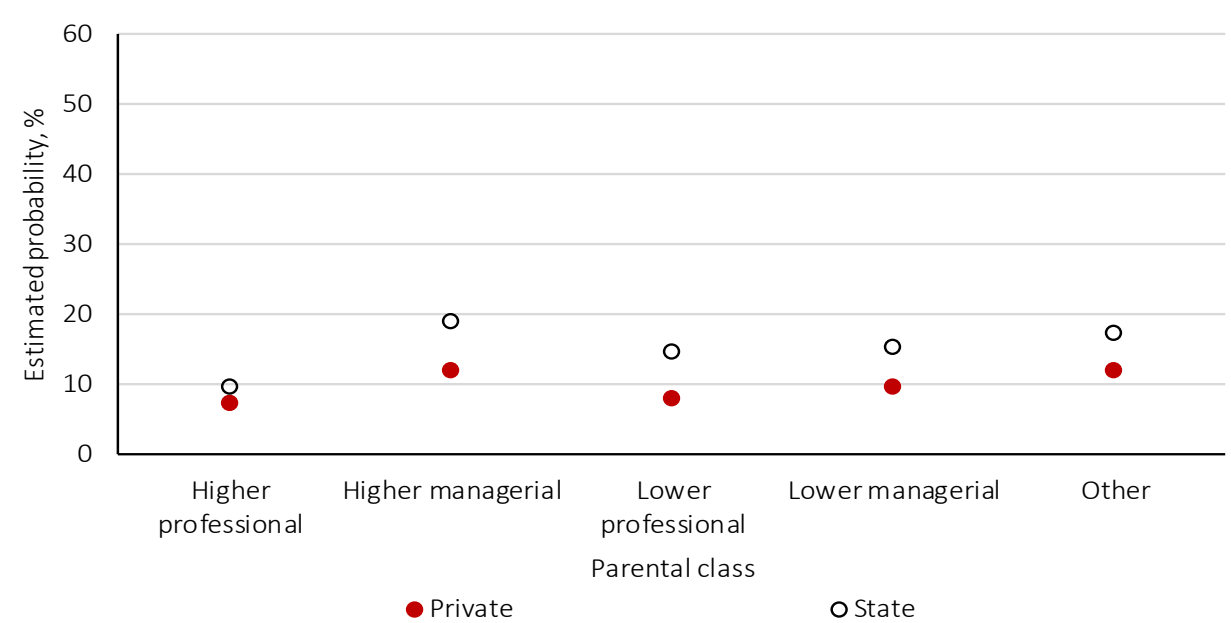

Other Biological Sciences; SAs 7, 8, 9, 10

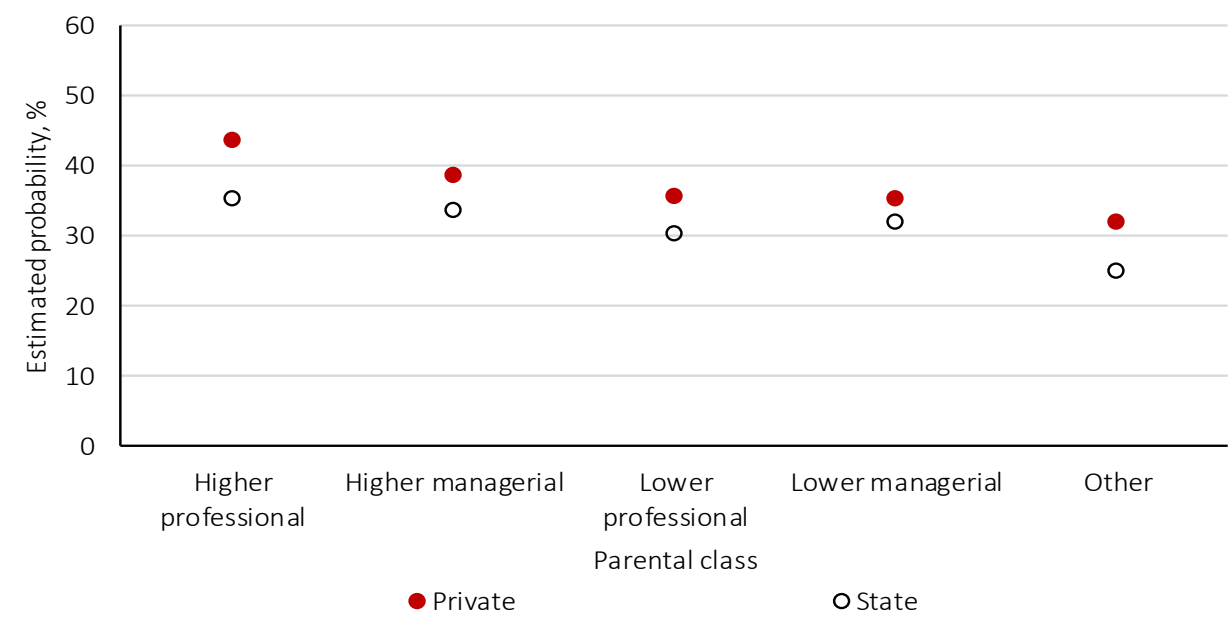

Note

(a) Based on a multinomial logit model that includes parental class, type of secondary school and interaction between these two variables.

(b) Birth cohort is also included as a control variable. 